\title{
Rationally Designed Vaccines Targeting the V2 Region of HIV-1 gp120 Induce a Focused, Cross-Clade-Reactive, Biologically Functional Antibody Response
}

\author{
(D) Susan Zolla-Pazner, ${ }^{a}$ Rebecca Powell, ${ }^{a}$ Sara Yahyaei, ${ }^{a}$ Constance Williams, ${ }^{\text {b }}$ Xunqing Jiang, ${ }^{\mathbf{b}}$ Wei Li, ${ }^{\mathrm{c}}$ Shan Lu, ${ }^{\mathrm{c}}$ Shixia Wang, \\ Chitra Upadhyay, ${ }^{a}$ Catarina E. Hioe, ${ }^{a}$ Max Totrov, ${ }^{d}$ Xiangpeng Kong ${ }^{b}$ \\ Departments of Medicine (Division of Infectious Diseases) and Microbiology, Icahn School of Medicine at Mount Sinai, New York, New York, USA; ; Department of \\ Biochemistry and Office of Science and Research, New York University School of Medicine, New York, New York, USA ${ }^{\text {; }}$ Department of Medicine, University of \\ Massachusetts Medical School, Worcester, Massachusetts, USAc; Molsoft, LLC, San Diego, California, USA ${ }^{\text {d }}$
}

\section{ABSTRACT}

Strong antibody $(\mathrm{Ab})$ responses against V1V2 epitopes of the human immunodeficiency virus type 1 (HIV-1) gp120 envelope (Env) correlated with reduced infection rates in studies of HIV, simian-human immunodeficiency virus (SHIV), and simian immunodeficiency virus (SIV). In order to focus the Ab response on V1V2, we used six V1V2 sequences and nine scaffold proteins to construct immunogens which were tested using various immunization regimens for their ability to induce cross-reactive and biologically active V2 Abs in rabbits. A prime/boost immunization strategy was employed using gp120 DNA and various V1V2scaffold proteins. The rabbit polyclonal Ab responses (i) were successfully focused on the V1V2 region, with weak or only transient responses to other Env epitopes, (ii) displayed broad cross-reactive binding activity with gp 120s and the V1V2 regions of diverse strains from clades $\mathrm{B}, \mathrm{C}$, and $\mathrm{E}$, (iii) included V2 Abs with specificities similar to those found in HIV-infected individuals, and (iv) remained detectable $\geq 1$ year after the last boosting dose. Importantly, sera from rabbits receiving V1V2-scaffold immunogens displayed Ab-dependent cellular phagocytosis whereas sera from rabbits receiving only gp120 did not. The results represent the first fully successful example of reverse vaccinology in the HIV vaccine field with rationally designed epitope scaffold immunogens inducing Abs that recapitulate the epitope specificity and biologic activity of the human monoclonal Abs from which the immunogens were designed. Moreover, this is the first immunogenicity study using epitope-targeting, rationally designed vaccine constructs that induced an Fc-mediated activity associated with protection from infection with HIV, SIV, and SHIV.

\section{IMPORTANCE}

Novel immunogens were designed to focus the antibody response of rabbits on the V1V2 epitopes of HIV-1 gp120 since such antibodies were associated with reduced infection rates of HIV, SIV, and SHIV. The vaccine-induced antibodies were broadly cross-reactive with the V1V2 regions of HIV subtypes B, C and E and, importantly, facilitated Fc-mediated phagocytosis, an activity not induced upon immunization of rabbits with gp120. This is the first immunogenicity study of vaccine constructs that focuses the antibody response on V1V2 and induces V2-specific antibodies with the ability to mediate phagocytosis, an activity that has been associated with protection from infection with HIV, SIV, and SHIV.

N onneutralizing antibodies (Abs) can protect against various viral infections, contributing to protection from alphaviruses, flaviviruses, respiratory syncytial virus (RSV), and cytomegalovirus, among others (reviewed in references 1 and 2). While the specificity and affinity of nonneutralizing Abs are dependent on the Fab fragment of Abs to target virions and infected cells, many of the biologic activities of these Abs are a function of the Fc fragment. Such activities include Ab-dependent cellular cytotoxicity (ADCC), Ab-dependent cellular phagocytosis (ADCP), Abdependent cell-mediated virus inhibition (ADCVI), complement activation and fixation, degranulation, and the release of proinflammatory cytokines (3). Specific examples include protection from herpes simplex virus 2 in mice by nonneutralizing Abs which mediate ADCC (4-6) and protection from influenza virus in mice by nonneutralizing Abs targeting the head or stalk of the influenza virus hemagglutinin $(7,8)$

Fc-mediated nonneutralizing Ab functions also play a role in reducing and preventing infection with simian immunodeficiency virus (SIV), simian-human immunodeficiency virus (SHIV), and human immunodeficiency virus (HIV) and in controlling virus replication in vivo (9-18). As early as 2004, vaccine-elicited Abs were shown to mediate ADCC, which correlated with reduced acute viremia in rhesus macaques challenged with $\operatorname{SIV}_{\text {mac251 }}$ (19, 20). Subsequently, a myriad of studies have shown that nonneutralizing Abs mediating ADCC and other Fc-dependent activities can prevent or contribute to control of SIV (21-23) and SHIV

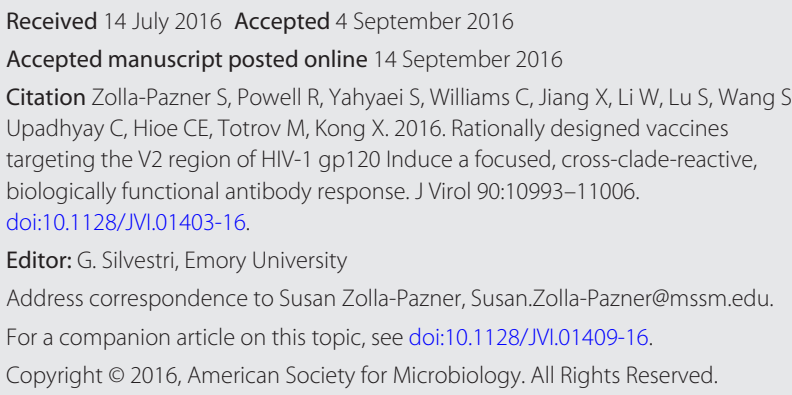


TABLE 1 Sequence of V1 and V2 variable loops in immunogens and antigens ${ }^{a}$

\begin{tabular}{lll}
\hline Strain $($ clade $)$ & V1 sequence & V2 sequence \\
\hline $1086(\mathrm{C})$ & CVTLNCTNVKGNESDTSEVMKN & CSFKATTELKDKKHKVHALFYKLDVVPLNGNSSSSGEYRLINC \\
A244 (E) & CVTLHCTNANLTKANLTNVNNRTNVSNIIGNITDEVRN & CSFNMTTELRDKKQKVHALFYKLDIVPIEDNNDSSEYRLINC \\
$92 \mathrm{TH} 023(\mathrm{E})$ & CVTLNCTNANVTNVKNITNVPNIIGNITDEVRN & CSFNMTTELRDKKQKVHALFYKLDIVPIEDNTSSSEYRLINC \\
Case A2 (B) & CVTLNCIDLRNATNATSNSNTTNTTSSSGGLMMEQGEIKN & CSFNITTSIRDKVQKEYALFYKDIVPIDNPKNSTNYRLISC \\
YU2 (B) & CVTLNCTDLRNATNTTSSSWETMEKGEIKN & CSFNITTSIRDKVQKEYALFYNLDVVPIDNASYRLISC \\
ZM109 (C) & CVTLNCTSPAAHNESETRVKH & CSFNITTDVKDRKQKVNATFYDLDIVPLSSSDNSSNSSLYRLISC \\
CAP45 (C) & CVTLRCTNATINGSLTEEVKN & CSFNITTELRDKKQKAYALFYRPDVVPLNKNSPSGNSSEYILINC \\
ZM53 (C) & CVTLNCSKLNNATDGEMKN & CSFNATTELRDKKKQVYALFYKLIVPLDGRNNSSEYRLINC \\
$\mathrm{cV2}^{\circ}(\mathrm{E})$ & & CSFNMTTELRDKKQKVHALFKLDIVPIEDNTSSSEYRLINC \\
\hline
\end{tabular}

${ }^{a}$ Cyclic V2 ${ }_{92 \mathrm{TH} 023}$ peptide.

(23-26). Significantly, Abs that mediate ADCC have been found in human breast milk and correlate with reduced risk of transmission from mother to infant (27).

Several streams of data from the RV144 clinical vaccine trial also suggest that reduced rates of HIV infection are associated with Abs that mediate ADCC and ADCP, but, notably, no correlation with the presence of serum neutralizing Abs was identified in RV144 vaccinees (10-18). The protective role for Fc-mediated Ab function is further supported by the finding that specific alleles of Fc $\gamma$ RIIc (which carries the extracellular sequence of Fc $\gamma$ RIIa, a critical participant in ADCP) were associated with RV144 vaccine efficacy (10). Moreover, the V2-specific IgG Ab levels, which were an independent correlate of a reduced infection rate in RV144 vaccinees $(13,28-31)$, appear to have played a role in the Fcmediated vaccine-induced antiviral activities in that V2 Abs contributed to ADCC responses $(14,16)$ and were found to synergize with constant region 1 (C1)-specific Abs that were also induced by the vaccine (11). V2-specific Abs have also been identified as correlates of protection after immunization and challenge with SIV (32-34).

Given these findings in monkeys and humans, we hypothesized that targeting the $\mathrm{Ab}$ response to $\mathrm{V} 2$ with rationally designed immunogens would improve the functional $\mathrm{Ab}$ quality and provide a basis for enhanced efficacy of HIV immunization protocols. In the work described below, we tested the immunogenicity of 12 V1V2-scaffold protein immunogens. The results show the induction of V2-specific Abs that are reactive with V1V2 and with gp120 Envs from diverse strains and clades. After priming with gp120 DNA with or without V1V2-scaffold protein immunogens and boosting with V1V2-scaffold proteins, a durable Ab response was successfully focused on the V1V2 region. This is the first immunogenicity study using rationally designed V1V2-targeting vaccine constructs. Similar to the results of previously published studies with V3-scaffold immunogens $(35,36)$, the V1V2-scaffold immunogens induced Abs that recapitulate the specificity and activities of the human V1V2-specific monoclonal antibodies (MAbs) whose epitopes were used as templates for the design of the V1V2-scaffold immunogens (37); importantly, the induced Abs display a biologic activity - in this case, Fc-mediated ADCPwhich has been associated with protection from infection with HIV, SHIV, and SIV $(12,18,24,38)$.

\section{MATERIALS AND METHODS}

Use of a codon-optimized HIV Env DNA, recombinant V1V2-scaffold proteins, and various protein and peptide antigens. Codon-optimized gp120 DNA expressing env from HIV clade C primary isolate ZM109F
(39) was prepared in the pJW4303 vector with a tissue plasminogen activator (tPA) leader sequence, as described previously $(40,41)$. The genes of the following proteins were used to prepare the scaffolds of the V1V2scaffold immunogens: PDB accession number 1FD6 (42), typhoid toxin subunit B (TTB) (43), and PDB accession numbers 2J9C (44) and 2F5K (45). The V1V2 sequences of the full-length V1V2 regions used as inserts into the scaffolds are listed in Table 1. Genes of the V1V2 scaffolds were chemically synthesized and cloned into the pVRC8400 plasmid, followed by expression in HEK293 $\mathrm{GnTI}^{-1-}$ cells and purification by affinity chromatography (46). Details of the design and construction of the immunogens are described separately (47). The V1V2-tags protein of strain 1086 (V1V2 ${ }_{1086}$-tags) and V1V2 $_{\mathrm{A} 244^{-}}$tags were provided by H. Liao (Duke University), $\mathrm{V} 1 \mathrm{~V} 2_{\mathrm{CaseA}_{2}}{ }^{-\mathrm{gp} 70}$ and $\mathrm{V} 1 \mathrm{~V} 2_{92 \mathrm{TH} 023}$-gp70 were provided by $\mathrm{A}$ Pinter, and gp $120_{\mathrm{A} 244}$ was provided by Global Solutions for Infectious Diseases (South San Francisco, CA). gp120 $\mathrm{BaL}, \mathrm{gp} 120_{\mathrm{ZM} 53}$, and gp $120_{\mathrm{ZM} 233}$ were purchased from Immune Tech (New York, NY), and a clade C V3 consensus linear, nonbiotinylated 23-mer peptide (NNTRKS IRIGPGQTFYATGDIIG) and the cyclic V2 $2_{92 \mathrm{TH} 023}\left(\mathrm{cV} 2_{92 \mathrm{TH} 023}\right.$, clade E) biotinylated peptide were purchased from BioPeptide (San Diego, CA). A C5 linear nonbiotinylated 22-mer peptide (amino acids 495 to 516 of gp120, KIEPLGVAPWKAKRRVVQREKR) was purchased from PolyPeptide Group (Torrance, CA).

Immunization protocol. Female New Zealand White rabbits, 6 to 8 weeks old (with a body weight of $\sim 2 \mathrm{~kg}$ ), were purchased from Harlan Laboratories (Indianapolis, IN) and housed in the animal facility managed by the Department of Animal Medicine at the University of Massachusetts Medical School in accordance with an IACUC-approved protocol. Three to five rabbits were included in each immunization group. All rabbits received three DNA immunizations using a Bio-Rad Helios gene gun (Bio-Rad Laboratories, Hercules, CA). The gp120 DNA vaccine plasmids were coated onto $1.0-\mu \mathrm{m}$ gold beads at a ratio of $2 \mu \mathrm{g}$ of DNA per mg of gold. Each gene gunshot delivered $1 \mu \mathrm{g}$ of DNA into a total of 36 nonoverlapping sites on the shaved abdominal skin of each rabbit at each of the three priming immunizations. Several groups of rabbits received protein immunogens simultaneously with the three DNA priming immunizations as described below; in addition, all animals received two protein boosts. Each dose of protein immunogen was delivered as a bolus of 100 $\mu \mathrm{g}$ intramuscularly together with adjuvant. Blood was collected prior to immunization and 2 weeks after each immunization. Rabbits were bled periodically for up to 76 weeks after the initiation of the immunization protocol to assess the longevity of the $\mathrm{Ab}$ response. The immunization schedule for each of four rabbit experiments is shown in Table 2.

Enzyme-linked immunosorbent assay (ELISA) method. Immulon 4 plates were coated using $100 \mu \mathrm{l} /$ well of the designated antigen at a concentration of $1 \mu \mathrm{g} / \mathrm{ml}$ in carbonate buffer, $\mathrm{pH} 9.6$, and incubated overnight at $4{ }^{\circ} \mathrm{C}$. Plates were then washed six times with phosphate-buffered saline (PBS) $-0.05 \%$ Tween. Subsequently, $100 \mu \mathrm{l} /$ well of rabbit serum was added to the plates after dilution in RPMI medium containing $15 \%$ fetal bovine serum. Plates were incubated for $1.5 \mathrm{~h}$ at $37^{\circ} \mathrm{C}$. After six washes, bound Abs were detected by the addition of $100 \mu \mathrm{l} /$ well of a 
TABLE 2 Immunization schedule

\begin{tabular}{lllll}
\hline $\begin{array}{l}\text { Week } \\
\text { no. }\end{array}$ & Expt H1 & Expt H2 & Expt H3 & Expt H4 \\
\hline 0 & DNA prime 1 & DNA prime 1 & DNA prime 1 & DNA prime 1 \\
2 & DNA prime 2 & DNA prime 2 & DNA prime 2 & \\
4 & DNA prime 3 & DNA prime 3 & DNA prime 3 & DNA prime 2 \\
6 & & & & \\
8 & & & DNA prime 3 \\
10 & Protein boost 1 & Protein boost 1 & Protein boost 1 & \\
12 & & & & \\
14 & Protein boost 2 & Protein boost 2 & Protein boost 2 & Protein boost 1 \\
16 & & & & Protein boost 2 \\
18 & & & &
\end{tabular}

1:2,000 dilution (in PBS- $0.05 \%$ Tween) of alkaline phosphatase-conjugated mouse anti-rabbit IgG (Southern Biotech, Birmingham, AL) and incubated for $1.5 \mathrm{~h}$ at $37^{\circ} \mathrm{C}$. After six washes, $100 \mu \mathrm{l} /$ well of $10 \%$ diethanolamine substrate was added, and after $30 \mathrm{~min}$, the plates were read at $405 \mathrm{~nm}$ using a Sunrise Tecan microplate reader equipped with Magellan 6 software. All samples were tested in duplicate. Various V2 MAbs were used as positive controls, and MAb 1418, specific for parvovirus B19, was used as a negative control in each experiment. For assessment of MAb reactivity, the same method was employed, using $10 \mu \mathrm{g} / \mathrm{ml}$ of MAb and alkaline phosphatase-conjugated goat anti-human IgG (Southern Biotech) as the secondary $\mathrm{Ab}$.
Measurement of Ab-dependent cellular phagocytosis. Using the assay developed by Ackerman et al. (48), $10 \mu \mathrm{g}$ of biotinylated cV2 $2_{92 \mathrm{TH} 023}$ was conjugated to fluorescent NeutrAvidin beads (Invitrogen) according to the manufacturer's instructions. In addition, $20 \mu \mathrm{g}$ of gp $120_{\mathrm{ZM} 53}$ (Immune Technology) or V1V2 ${ }_{\mathrm{YU} 2}-1 \mathrm{FD} 6$ was biotinylated using EZ-Link sulfo-NHS-LC-LC-biotin (sulfosuccinimidyl-6-[biotinamido]-6-hexanamido hexanoate; Thermo Scientific), and these reagents were also conjugated to fluorescent NeutrAvidin beads. Conjugated beads were washed and resuspended in $0.1 \%$ bovine serum albumin (BSA)-PBS to a working dilution of 1:100. A total of $9 \times 10^{5}$ beads were aliquoted per well in round-bottom 96-well plates. Fourfold dilutions of a MAb or 2-fold dilutions of individual serum samples were added, incubated for $2 \mathrm{~h}$ at $37^{\circ} \mathrm{C}$, and washed. A total of $2.5 \times 10^{4}$ THP- 1 cells (ATCC) were added to each well and incubated overnight. Phagocytosis was measured by flow cytometry. ADCP scores were calculated as follows: (percentage of bead-positive cells $\times$ MFI of bead-positive cells) $/ 10^{6}$, where MFI is mean fluorescence intensity.

\section{RESULTS}

Immunogenicity study design. Eighteen different vaccination regimens were performed during the course of four rabbit experiments ( $\mathrm{H} 1$ to $\mathrm{H} 4$ ) (Table 3 ) using 95 rabbits to test the immunogenicity of 12 vaccines constructed with six V1V2 sequences presented on one of nine protein scaffolds and administered intramuscularly with one of two adjuvants. Each immunization regimen was tested in three to five animals. All groups (with the

TABLE 3 Immunization protocol and ELISA results for rabbit experiments $\mathrm{H} 1$ to $\mathrm{H}^{a}{ }^{a}$

\begin{tabular}{|c|c|c|c|c|c|c|c|c|c|c|c|c|c|c|}
\hline \multirow[b]{2}{*}{$\begin{array}{l}\text { Expt/ } \\
\text { Group }\end{array}$} & \multirow{3}{*}{ Rabbit \#s } & Prime & \multicolumn{2}{|c|}{ Prime } & \multicolumn{2}{|c|}{ Protein Boost } & \multirow{3}{*}{ Adjuvant } & \multicolumn{7}{|c|}{ O.D. ( 2 weeks post-2 ${ }^{\text {nd }}$ boost: screen at $\left.1: 100\right)^{*}$} \\
\hline & & DNA & V1V2 & Scaffold & V1V2 & Scaffold & & $\begin{array}{c}\text { cV2 } \\
\text { 92TH023 }\end{array}$ & $\begin{array}{l}\text { V1V2I } \\
\text { A244- } \\
\text { tags }\end{array}$ & $\mid \begin{array}{c}\text { V1V2I } \\
1086 \text {-tags }\end{array}$ & $\begin{array}{c}\text { V1V2I } \\
\text { 92TH023- } \\
\text { gp70 }\end{array}$ & $\begin{array}{c}\text { V1V2I } \\
\text { YU2-1FD6 }\end{array}$ & $\begin{array}{c}\text { V1V2I } \\
\text { ZM109- } \\
\text { 1FD6 }\end{array}$ & $\begin{array}{l}\text { V1V2/ZM109 } \\
\text { (N160K)-1FD6 }\end{array}$ \\
\hline Clade & & & & & & & & E & $\mathbf{E}$ & C & E & B & c & c \\
\hline H1/1 & $1-5$ & ZM109F-opt gp120 & - & - & Case A2 (B) & gp70 & IFA & 1.3 & 1.5 & 1.9 & 2.9 & 0.4 & 1.6 & 1.6 \\
\hline$H 1 / 2$ & 6-10 & ZM109F-opt gp120 & - & - & 1086 & Tags & IFA & 0.6 & 1.9 & 2.4 & 1.9 & 0.2 & 1.0 & 1.1 \\
\hline $\mathrm{H} 1 / 3$ & $11-15$ & ZM109F-opt gp120 & - & - & ZM109 & 1FD6 & IFA & 1.0 & 0.9 & 0.5 & 1.1 & 1.5 & 2.3 & 2.9 \\
\hline H1/4 & $16-20$ & ZM109F-opt gp120 & - & - & CAP45 & 1FD6 & IFA & 0.9 & 1.0 & 1.0 & 1.5 & 1.2 & 2.0 & 2.5 \\
\hline $\mathrm{H} 1 / 5$ & $21-25$ & ZM109F-opt gp120 & - & - & ZM109 & gp120 & IFA & 1.9 & 1.6 & 1.8 & 2.4 & 0.2 & 2.4 & 3.1 \\
\hline $\mathrm{H} 2 / 1$ & $26-28$ & ZM109F-opt gp120 & - & - & ZM109 & gp120 & IFA & 2.5 & 1.4 & 1.3 & 1.7 & 0.1 & 1.9 & 2.3 \\
\hline $\mathrm{H} 2 / 2$ & 29-32 & ZM109F-opt gp120 & - & - & ZM53 & 2J9C & IFA & 0.6 & 0.8 & 0.8 & 0.4 & 1.0 & 2.1 & 1.7 \\
\hline $\mathrm{H} 2 / 3$ & $33-36$ & ZM109F-opt gp120 & - & - & 1086 & Fc & IFA & 0.5 & 1.3 & 2.8 & 1.3 & 0.1 & 0.7 & 0.4 \\
\hline H2/4 & $37-41$ & ZM109F-opt gp120 & - & - & ZM109 & 1FD6-Fc & IFA & 1.0 & 1.2 & 1.2 & 0.6 & 1.9 & 2.8 & 2.8 \\
\hline $\mathrm{H} 2 / 5$ & $42-46$ & ZM109F-opt gp120 & - & - & ZM109 & тTB & IFA & 0.4 & 0.4 & 0.4 & 0.2 & 1.0 & 1.9 & 1.8 \\
\hline $\mathrm{H} 2 / 6$ & $47-50$ & ZM109F-opt gp120 & - & - & ZM109 & 1 FD $6 \times$ СТВ & IFA & 1.1 & 0.8 & 0.7 & 0.6 & 1.0 & 1.8 & 1.8 \\
\hline $\mathrm{H} 3 / 1$ & $51-55$ & ZM109F-opt gp120 & - & - & ZM53 & $2 \mathrm{~F} 5 \mathrm{~K}$ & IFA & 1.1 & 1.4 & 2.1 & 1.8 & 1.8 & 2.5 & 3.0 \\
\hline $\mathrm{H} 3 / 2$ & $56-60$ & ZM109F-opt gp120 & - & - & ZM109 & 1FD6-Fc & IFA & 0.7 & 0.8 & 0.7 & 1.0 & 1.7 & 1.8 & 2.7 \\
\hline $\mathrm{H} 3 / 3$ & $61-65$ & ZM109F-opt gp120 & - & - & ZM109 & Fc & IFA & 1.3 & 1.1 & 1.6 & 1.6 & 1.8 & 2.8 & 3.2 \\
\hline $\mathrm{H} 3 / 4$ & $66-70$ & ZM109F-opt gp120 & ZM53 & 2J9C & ZM53 & 2J9C & IFA & 1.3 & 1.7 & 2.3 & 1.4 & 2 & 3.0 & 3.2 \\
\hline $\mathrm{H} 3 / 5$ & $71-75$ & ZM109F-opt gp120 & ZM109 & ттв & ZM109 & тTВ & IFA & 0.8 & 0.7 & 1.2 & 0.8 & 1.7 & 3.0 & 3.2 \\
\hline $\mathrm{H} 4 / 1$ & $76-80$ & ZM109F-opt gp120 & ZM53 & 2J9C & ZM53 & 2J9C & Alum & 0.7 & 1.6 & 0.9 & 0.9 & 1.0 & 2.0 & 1.8 \\
\hline $\mathrm{H} 4 / 2$ & $81-85$ & ZM109F-opt gp120 & ZM53 & 2J9C & ZM53 & 2J9C & IFA & 1.3 & 2.2 & 1.2 & 1.9 & 1.7 & 3.3 & 2.8 \\
\hline $\mathrm{H} 4 / 3$ & $86-90$ & - & ZM53 & 2J9C & ZM53 & 2J9C & IFA & 0.7 & 1.8 & 0.6 & 1.2 & 1.5 & 3.2 & 2.8 \\
\hline $\mathrm{H} 4 / 4$ & $91-95$ & ZM109F-opt gp120 & ZM53 & 2J9C & A244 & 2J9C & IFA & 0.5 & 1.1 & 0.3 & 0.5 & 1.0 & 2.5 & 2.3 \\
\hline
\end{tabular}

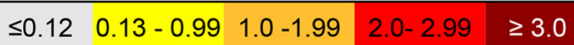

\footnotetext{
${ }^{a}$ The reactivity of prebleed sera diluted 1:100 against each of the antigens gave an optical density reading of $\leq 0.12$.
} 
exception of group 3 from experiment H4 [H4/3]) (Table 3) were primed with codon-optimized DNA of gp120 from clade C strain ZM109F, as indicated in Table 3; the timing of each immunizing dose is shown in Table 2. Five groups of animals were coimmunized with DNA and protein, followed by protein-only boosting (Table 3).

Characterization of the $\mathrm{Ab}$ response. Rabbits were bled prior to and 2 weeks after each immunization. For all rabbits, the sera drawn 2 weeks after the last boost were used at 1:100 dilutions to screen by ELISA for reactivity against various V1V2 antigens. The results in Table 3 show the mean optical densities (ODs) from all animals in each group when sera were tested for $\mathrm{Ab}$ reactivity with a variety of antigens carrying the V1V2 region from various clades and in various configurations. Thus, $\mathrm{CV}_{92 \mathrm{TH} 023}$ (clade E), V1V2 ${ }_{1086}$-tags (clade C), V1V2 ${ }_{\mathrm{A} 244}$-tags (clade E), and V1V2 ${ }_{92 \mathrm{TH} 023}$-gp70 (clade E) were present in an unconstrained configuration since the mobility of the V1V2 region was not limited by the structure of, or the placement in, the scaffold. In contrast, the flexibility of the V1V2 regions present in $\mathrm{V} 1 \mathrm{~V} 2_{\mathrm{YU} 2}-1 \mathrm{FD} 6$ (clade B), V1V2 ${ }_{\mathrm{ZM} 109^{-1 F D 6}}$ (clade C), and the N160K mutant of V1V2 $2_{\mathrm{ZM} 109}-1$ FD6 was constrained by its placement in the 1FD6 scaffold (49). The reagents used here have been described previously $(16,30,49,50)$. Reactivity of prebleed sera, diluted 1:100, against each of these antigens gave OD readings of $\leq 0.12$. Sera drawn from animals after two boosts with all of the immunization regimens were reactive above the prebleed background levels with essentially all antigens, indicating that all of the various V1V2-scaffold proteins were immunogenic and induced Abs that were highly cross-clade reactive with epitopes displayed by diverse V1V2 regions. The pattern evident from the heat map of ELISA reactivities shown in Table 3 indicates that the strongest responses were in animals immunized with immunogens bearing constrained V1V2 epitopes (displayed on scaffolds 1FD6, 2J9C, 1FD6-Fc, TTB, and 2F5K) and tested with ELISA antigens displaying V1V2-constrained epitopes [V1V2 ${ }_{\mathrm{YU}_{2}}-1 \mathrm{FD} 6, \mathrm{~V} 1 \mathrm{~V} 2_{\mathrm{ZM} 109^{-}}$ 1 FD6, and $\left.\mathrm{V} 1 \mathrm{~V} 2_{\mathrm{ZM} 109(\mathrm{~N} 160 \mathrm{~K})}\right)^{-1 \mathrm{FD} 6}$. The $P$ value using a onetailed Student $t$ test was 0.0035 when the OD values derived using the three V1V2-constrained ELISA antigens and sera of animals immunized with V1V2-constrained immunogens were compared to the OD values of ELISAs derived from sera of rabbits immunized with V1V2-unconstrained immunogens (displayed as part of gp70, tags, gp120, or Fc). The Ab response was also stronger when protein immunogen was included with the DNA priming immunization and not just in the boost $(\mathrm{H} 2 / 2$ versus groups $\mathrm{H} 3 / 4$ and $\mathrm{H} 4 / 2$, where the protein immunogen was $\mathrm{V} 1 \mathrm{~V} 2_{\mathrm{ZM} 53}-2 \mathrm{~J} 9 \mathrm{C}$ $[P=0.001$ by the one-tailed Mann-Whitney test $])$. This reproduces previously published data (51).

As shown previously, V1, V2, and V3 form the apex of the envelope trimer on the surface of virions and infected cells (5254). Three categories of Abs have been described which are specific for different epitope regions in V1V2 $(55,56)$, as follows.

(i) V $2 \mathrm{p}$ Abs target a linear epitope represented by a peptide from the $\mathrm{C}$ strand of $\mathrm{V} 2$, which assumes a helical structure when bound to V2p MAbs. Only a few such human V2p-specific MAbs have been described, and these appear to be quite limited in their neutralizing ability but are able to mediate $\operatorname{ADCC}(16,57)$. V2pspecific Abs were generated in the studies described herein as rabbit sera bound to the cyclic peptide $\mathrm{cV} 2_{92 \mathrm{TH} 023}$ (Table 3 ), a reagent which is recognized only by $\mathrm{V} 2 \mathrm{p}$-specific monoclonal Abs (MAbs) (Fig. 1). (ii) V2i Abs target a highly conformational epitope that includes the integrin binding site at residues 179 to $181(55,56)$. Many V2i MAbs have been described, and serum V2i Abs exist in the majority of infected individuals (58-60); these polyclonal and monoclonal Abs do not react with V2-derived peptides but are highly cross-reactive with monomeric gp120 from diverse strains and clades (61) as well as with V1V2-scaffolded proteins such as V1V2 ${ }_{\text {CaseA2-gp70 (Fig. 1) }}(58,59)$. Binding of serum Abs to

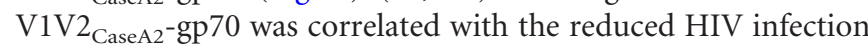
rate in RV144 vaccinees, demonstrating that the RV144 vaccine regimen induced V2i-like Abs $(13,28,30)$. Several of the reagents used to interrogate rabbit immune sera were able to bind to V2i

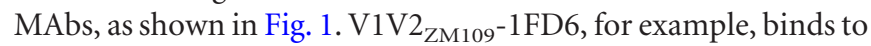
several V2i MAbs, but V2i MAbs do not bind to the $\mathrm{CV} 29_{2 \mathrm{TH} 023}$ peptide. As shown in Table 3, immune sera from all rabbits bind strongly to $\mathrm{V} 1 \mathrm{~V} 2_{\mathrm{ZM} 109}-1 \mathrm{FD} 6$.

(iii) V2q, also designated as V2 apex Abs, such as MAbs PG9 and $\mathrm{CH} 01(62,63)$ preferentially target a V1V2 peptidoglycan which is part of the structure created by the quaternary interaction of the three V1V2 domains in the Env trimer $(62,64)$. These MAbs mediate broad and potent neutralization, and, for avid binding, these $\mathrm{V} 2 \mathrm{q}$ MAbs require the presence of the glycan at position N160 (62, 64). To determine if V2q-specific Abs were induced in immunized rabbits, we tested their ability to bind to an $\mathrm{N} 160 \mathrm{~K}$ mutant of V1V2 $2_{\mathrm{ZM} 109^{-1 F D 6}}$. As shown in Table 3, Abs in rabbit serum bound as well to V1V2 $2_{\mathrm{ZM} 109(\mathrm{~N} 160 \mathrm{~K})^{-1 F D 6}}$ as to $\mathrm{V} 1 \mathrm{~V} 2_{\mathrm{ZM} 109^{-}}$ 1FD6. In addition, rabbit immune serum did not mediate neutralization (see below). These data indicate that the Abs induced in the rabbits immunized with V1V2 scaffolds did not have the immunochemical or functional characteristics of the potent and broadly neutralizing V2q Abs.

To further characterize the responses to the various immunogens used here, $\mathrm{Ab}$ reactivities were compared when the boosting regimen used gp120 protein instead of various V1V2-scaffold immunogens. The data are shown in Fig. 2, in which immune sera from all animals in experiments $\mathrm{H} 2$, drawn 2 weeks after the second boost, were tested for reactivity with V1V2 ${ }_{\mathrm{ZM} 109^{-1 F D 6}}$. As expected, the prebleed sera showed no reactivity, while sera from all immunized rabbits reacted with $\mathrm{V} 1 \mathrm{~V} 2_{\mathrm{ZM} 109}-1$ FD6. Of particular import is that the levels of Abs in the animals boosted with various V1V2-scaffold immunogens (with the exception of $\mathrm{V} 1 \mathrm{~V} 2_{1086}-\mathrm{Fc}$ ) were comparable to the levels of Abs achieved in rabbits boosted with the gp $120_{\mathrm{ZM} 109}$ protein. Notably, the reciprocal of the geometric mean titer for 50\% neutralization $\left(\mathrm{GMT}_{50}{ }^{-1}\right)$ in gp120 $\mathrm{ZM109}$-boosted animals (Fig. 2, group H2/1) was 280 compared to the $\mathrm{GMT}_{50}{ }^{-1}$ value of 838 for animals boosted in the same experiment with V1V2 $2_{\mathrm{ZM} 109}-1 \mathrm{FD} 6-\mathrm{Fc}(P=$ 0.03 , by a one-tailed Mann-Whitney analysis). There appeared to be little if any contribution of anti-scaffold Abs to the $\mathrm{GMT}_{50}{ }^{-1}$ values (data not shown), which is consistent with the relatively small size and expected poor immunogenicity of the scaffolds; e.g., the molecular mass of 1FD6 is $6.3 \mathrm{kDa}$, that of TTB is $12.5 \mathrm{kDa}$, that of $2 \mathrm{~F} 5 \mathrm{~K}$ is $10.6 \mathrm{kDa}$, and that of $2 \mathrm{~J} 9 \mathrm{C}$ is $12.9 \mathrm{kDa}$.

Comparison of the efficacies of various immunization regimens. To compare a series of variables, radar plots were developed to indicate the mean levels in animal sera of Abs against six different antigens (Fig. 3). Each of the graphs (Fig. 3A to E) shows the mean OD values of all animals in each of two groups immunized to test a single variable. In all cases, the response of one group was 

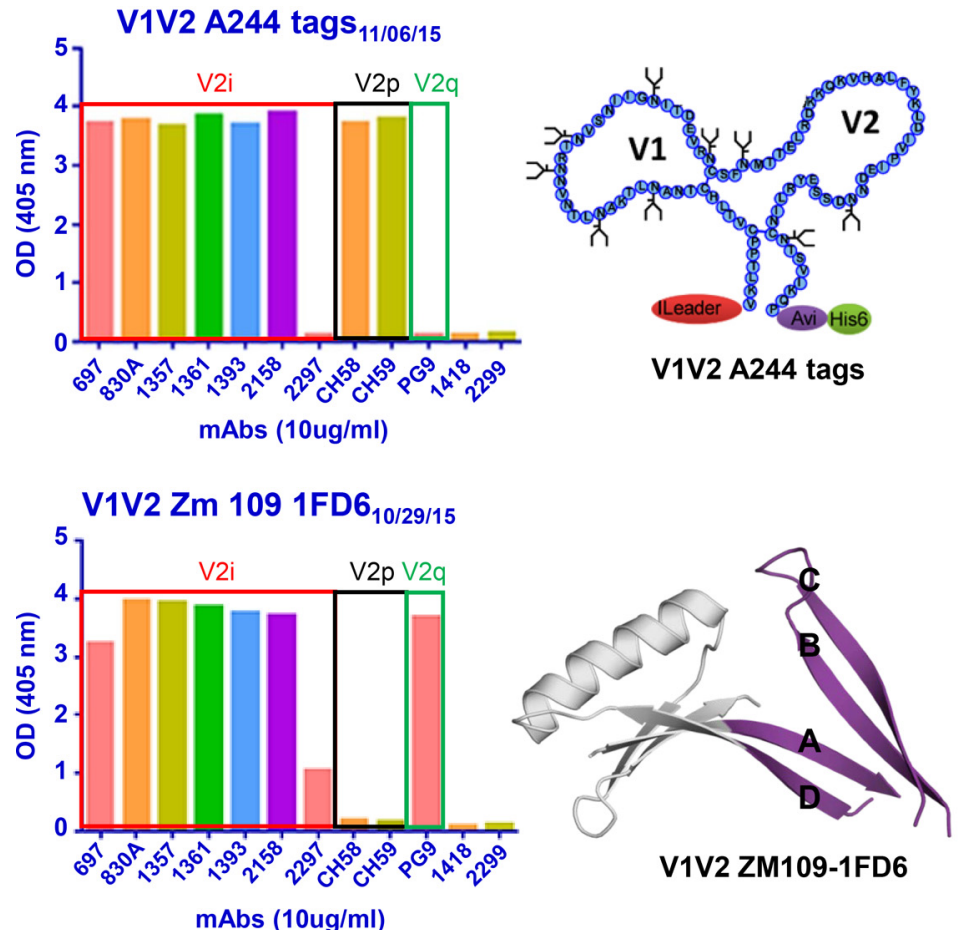

V1V2 ZM109-1FD6

FIG 1 Monoclonal antibody (MAb) reactivity against various V1V2 scaffolds. The optical densities (ODs) of the ELISA reactions between several human MAbs (used at dilutions of $10 \mu \mathrm{g} / \mathrm{ml}$ ) and various V1V2-scaffold antigens are shown. MAbs are designated specific for the V2i, V2p, or V2q epitope, as defined in the text. Diagrams of V1V2 ${ }_{\mathrm{A} 244}$-tags, of V1V2 $\mathrm{ZM109}-1 \mathrm{FD} 6$, and of $\mathrm{cV} 2_{92 \mathrm{TH} 023}$, which were used as antigens in these ELISAs, are shown. For V1V2 ${ }_{\mathrm{ZM} 109}-1 \mathrm{FD} 6$, V1V2 is shown in purple, and 1FD6 is in gray. The four strands, A, B, C, and D, of V1V2 are marked. Negative controls consisted of human MAb 1418, specific for parvovirus B19, and human MAb 2299, specific for gp70 of murine leukemia virus.

consistently stronger to all six antigens. For example, animals that were coprimed with gp120 DNA plus a V1V2-scaffold protein (either $\mathrm{V} 1 \mathrm{~V} 2_{\mathrm{ZM} 109}-\mathrm{TTB}$ or $\mathrm{V} 1 \mathrm{~V} 2_{\mathrm{ZM} 53}-2 \mathrm{~J} 9 \mathrm{C}$ ) and that received two boosts with the same V1V2-scaffold protein gave consistently c.1086 tags $\mathrm{V} 1 \mathrm{~V} 2_{10 / 29 / 15}$

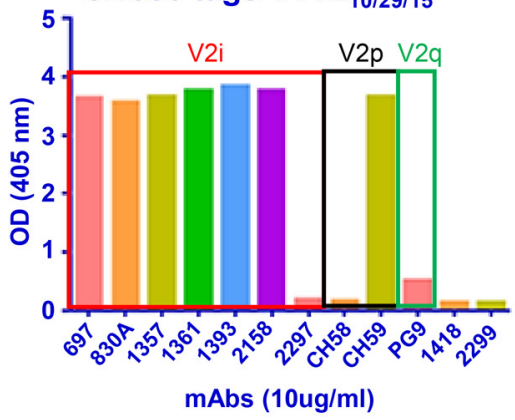

cV2 92Th023 $11 / 18 / 15$

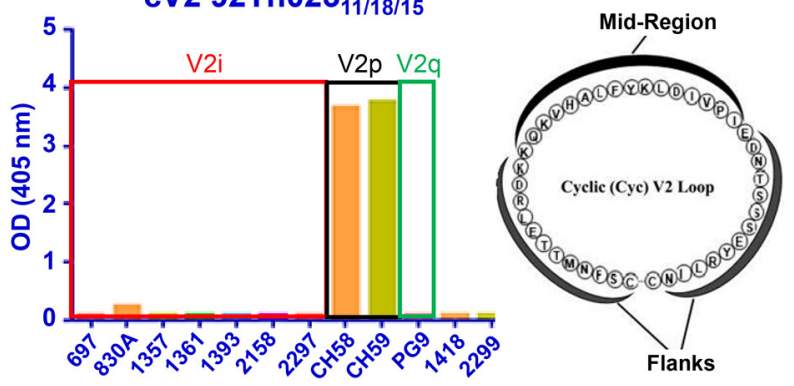

cV2 92Th023 stronger $\mathrm{Ab}$ responses against six $\mathrm{V} 1 \mathrm{~V} 2$ antigens than animals primed with gp120 DNA alone and boosted with a V1V2-scaffold protein (Fig. 3A and B).

The specifics of each panel in Fig. 3 are provided in Fig. 3F,
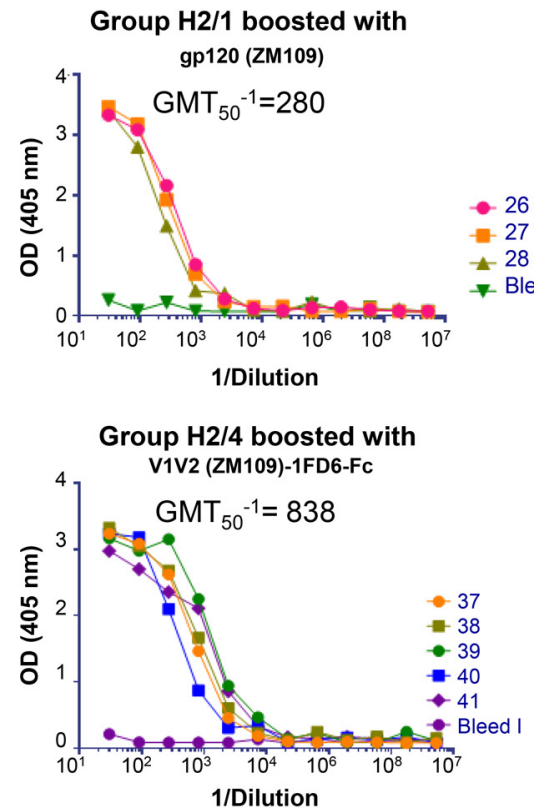

Group $\mathrm{H} 2 / 2$ boosted with V1V2 (ZM53)-2J9C
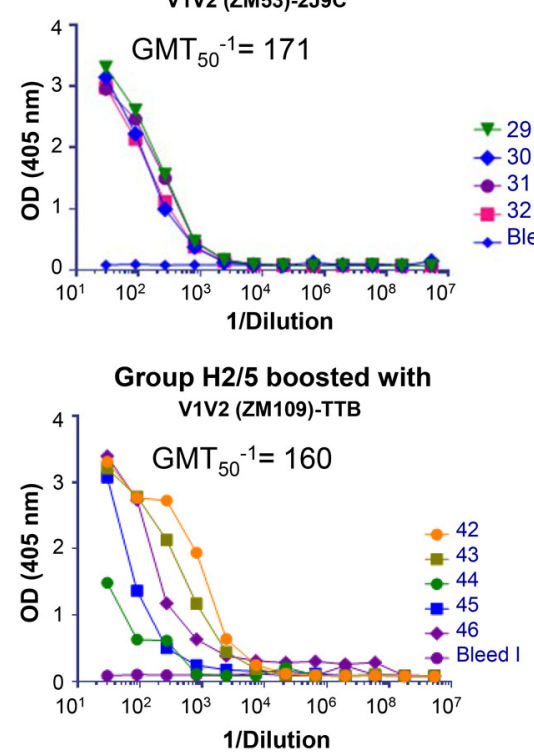

Group H2/3 boosted with V1V2 (1086)-Fc

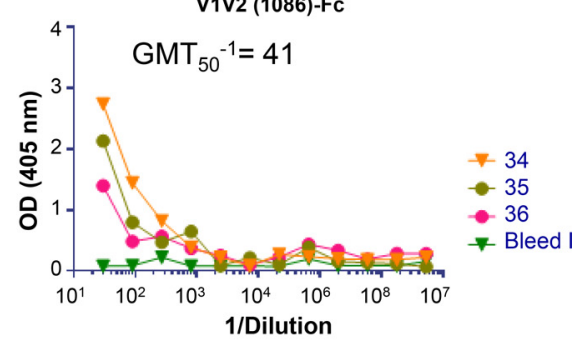

Group $\mathrm{H} 2 / 6$ boosted with V1V2 (ZM109)-1FD6 x CTB

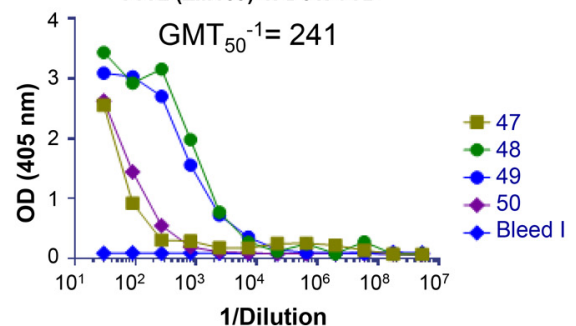

FIG 2 Titration of immune rabbit sera against V1V2 ${ }_{\mathrm{ZM} 109}-1$ FD6. Pools of prebleed sera (bleed I) from each group or serum drawn 2 weeks after the last boost from individual animals (numbered 26 to 50) in each of the six groups of animals immunized as part of experiment H2 (Table 3) were titrated in ELISAs. 

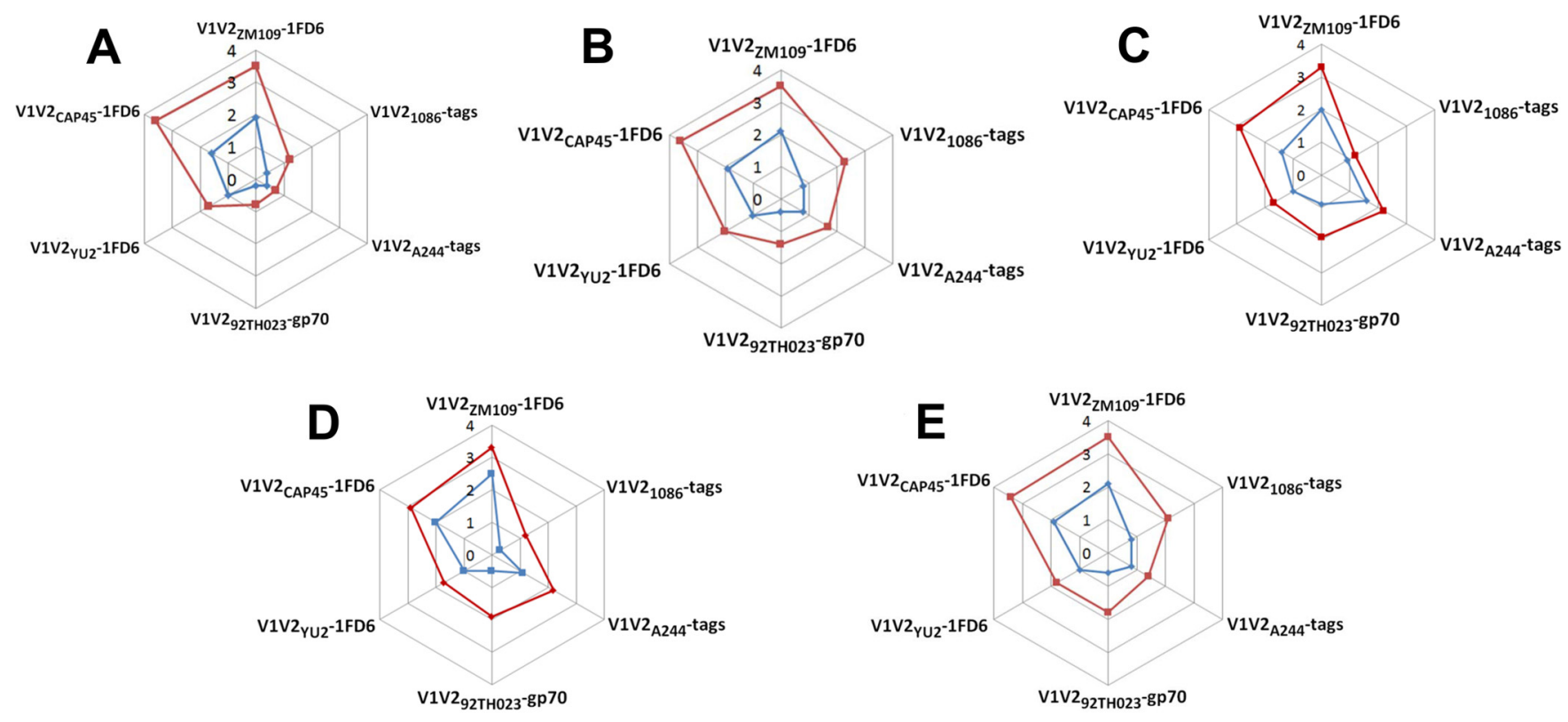

\begin{tabular}{|c|c|c|c|c|c|c|}
\hline Figure & Group & Prime $(\times 3)^{*}$ & Boost $(\times 2)^{*}$ & Adjuvant* & 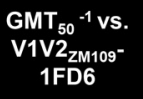 & $\begin{array}{c}\text { p-value } \\
\text { (one-tailed Mann } \\
\text { Whitney test) }\end{array}$ \\
\hline $3 A$ & $\begin{array}{l}\mathrm{H} 2 / 5 \\
\text { blue }\end{array}$ & DNA gp120/ZM109 & V1V2/ZM109-TTB & IFA & 160 & \multirow{2}{*}{0.041} \\
\hline $3 A$ & $\begin{array}{l}\mathrm{H} 3 / 5 \\
\text { red }\end{array}$ & $\begin{array}{l}\text { DNA gp120/ZM109 } \\
+ \text { V1V2/ZM109-TTB }\end{array}$ & V1V2/ZM109-TTB & IFA & 959 & \\
\hline 3B & $\begin{array}{l}\mathrm{H} 2 / 2 \\
\text { blue }\end{array}$ & DNA gp120/ZM109 & V1V2/ZM53-2J9C & IFA & 171 & \multirow{2}{*}{0.030} \\
\hline 3B & $\begin{array}{l}\mathrm{H} 3 / 4 \\
\text { red }\end{array}$ & $\begin{array}{l}\text { DNA gp120/ZM109 } \\
+ \text { V1V2/ZM53-2J9C }\end{array}$ & V1V2/ZM53-2J9C & IFA & 2246 & \\
\hline $3 C$ & $\begin{array}{l}\mathrm{H} 4 / 1 \text {; } \\
\text { blue }\end{array}$ & $\begin{array}{l}\text { DNA gp120/ZM109 } \\
+ \text { V1V2/ZM53-2J9C }\end{array}$ & V1V2/ZM53-2J9C & Alum & 37 & \multirow{2}{*}{0.029} \\
\hline $3 C$ & $\begin{array}{l}\mathrm{H} 4 / 2 \\
\text { red }\end{array}$ & $\begin{array}{l}\text { DNA gp120/ZM109 } \\
+ \text { V1V2/ZM53-2J9C }\end{array}$ & V1V2/ZM53-2J9C & IFA & 149 & \\
\hline 3D & $\begin{array}{l}\mathrm{H} 4 / 4 ; \\
\text { blue }\end{array}$ & $\begin{array}{l}\text { DNA gp120/ZM109 } \\
+ \text { V1V2/ZM53-2J9C }\end{array}$ & V1V2/A244-2J9C & IFA & 22 & \multirow{2}{*}{0.022} \\
\hline 3D & $\begin{array}{l}\mathrm{H} 4 / 2 ; \\
\text { red }\end{array}$ & $\begin{array}{l}\text { DNA gp120/ZM109 } \\
+ \text { V1V2/ZM53-2J9C }\end{array}$ & V1V2/ZM53-2J9C & IFA & 149 & \\
\hline $3 \mathrm{E}$ & $\begin{array}{l}\mathrm{H} 2 / 2 \\
\text { blue }\end{array}$ & DNA gp120/ZM109 & V1V2/ZM53-2J9C & IFA & 171 & \multirow{2}{*}{0.001} \\
\hline $3 E$ & $\begin{array}{l}\mathrm{H} 3 / 1 \\
\text { red }\end{array}$ & DNA gp120/ZM109 & $\underline{\text { V1V2/ZM53-2F5K }}$ & IFA & 1412 & \\
\hline
\end{tabular}

FIG 3 Radar graphs showing antibody responses in sera obtained from immunized rabbits drawn 2 weeks after the second boost. (A to E) Mean OD values are shown for sera diluted 1:100. (F) Details of the immunization of each group of animals, along with the geometric mean reciprocal half-maximal titers of sera from individual rabbits in each group $\left(\mathrm{GMT}_{50}{ }^{-1}\right)$, are shown for ELISAs in which V1V2 ${ }_{\mathrm{ZM10}}-1 \mathrm{FD} 6$ was used as the coating antigen. ${ }^{*}$, underlining denotes the difference in the immunization regimens between the two experiments in each pair compared.

which also shows the $\mathrm{GMT}_{50}{ }^{-1}$ values against one of the antigens, V1V2 $2_{\text {ZM109 }}-1$ FD6, for each group. For example, for the data shown in Fig. $3 \mathrm{~A}$ where V1V2 $\mathrm{ZM} 109^{-\mathrm{TTB}}$ was used as the protein immunogen, the $\mathrm{GMT}_{50}{ }^{-1}$ levels for the two different priming strategies (DNA plus protein versus DNA alone) were 959 and 160, respectively; similarly, for the data shown in Fig. 3B where $\mathrm{V} 1 \mathrm{~V} 2_{\mathrm{ZM} 53}-2 \mathrm{~J} 9 \mathrm{C}$ was used as the protein immunogen, the $\mathrm{GMT}_{50}{ }^{-1}$ levels for the two different priming strategies (DNA plus protein versus DNA alone) were 2,246 and 171, respectively
(Fig. 3F). The $P$ values generated with a one-tailed MannWhitney test are shown to be significant for each of the pairs compared (Fig. 3F).

Animals that were coprimed three times with DNA and the $\mathrm{V} 1 \mathrm{~V} 2_{\mathrm{ZM} 53}-2 \mathrm{~J} 9 \mathrm{C}$ protein and then boosted with $\mathrm{V} 1 \mathrm{~V} 2_{\mathrm{ZM} 53}-2 \mathrm{~J} 9 \mathrm{C}$ using incomplete Freund's adjuvant (IFA) gave stronger responses than animals receiving the same immunization regimen using alum as an adjuvant (Fig. $3 \mathrm{C}$ ). The $\mathrm{GMT}_{50}{ }^{-1}$ values of the sera from the animals in these groups, when titrated against 
TABLE 4 Duration of the antibody response during and after priming with gp $120_{\mathrm{ZM} 109}$ DNA and boosting with gp $120_{\mathrm{ZM} 109}\left(\right.$ experimental group H1/5) ${ }^{a}$

\begin{tabular}{|c|c|c|c|c|c|c|c|}
\hline BLEED & Week & & $\begin{array}{c}\text { ZM233 } \\
\text { gp120 }\end{array}$ & $\begin{array}{c}\text { V1V2/ } \\
\text { YU2- } \\
\text { 1FD6 }\end{array}$ & $\begin{array}{c}\text { V1V2/ } \\
\text { ZM109-TTB }\end{array}$ & $\begin{array}{c}\text { V1V2/Case A2- } \\
\text { gp70 }\end{array}$ & V3 ConsC \\
\hline I & 0 & $\begin{array}{c}\text { Pre- } \\
\text { bleed }\end{array}$ & 0.17 & $0.09 \ddagger$ & 0.12 & 0.09 & 0.08 \\
\hline II & 2 & $2 w p 1 p^{*}$ & 0.36 & 0.09 & 0.19 & 0.10 & 0.09 \\
\hline III & 4 & $2 w p 2 p$ & 2.21 & 0.09 & 0.23 & 0.24 & 0.17 \\
\hline IV & 6 & $2 w p 3 p$ & 2.87 & 0.09 & 0.36 & 0.64 & 0.24 \\
\hline V & 10 & $6 w p 3 p$ & 2.02 & 0.10 & 0.26 & 0.57 & 0.11 \\
\hline VI & 12 & $2 w p 1 b$ & 2.98 & 0.31 & 0.84 & 1.62 & 0.44 \\
\hline VII & 16 & $2 w p 2 b$ & 2.97 & 0.34 & 1.06 & 2.07 & 0.52 \\
\hline VIII & 18 & $4 w p 2 b$ & 3.03 & 0.34 & 1.01 & 2.31 & 0.72 \\
\hline IX & 21 & $7 w p 2 b$ & 2.86 & 0.27 & 0.91 & 1.81 \\
\hline
\end{tabular}

${ }^{a}$ Values are the mean ODs at $405 \mathrm{~nm}$ of five sera tested at 1:100. Data from 36 prebleed sera in various experiments were used to calculate a cutoff value (mean +3 standard deviations) of $\geq 0.14$. The results during priming are shown in bleeds I to $\mathrm{V}$, and those during and after boosts are represented in bleeds VI to IX. Abbreviations for the prime-boost regimen use the following form: 2 wplp, 2 weeks post-1st prime; 2 wplb, 2 weeks post-1st boost. V3 ConsC, V3 consensus C peptide.

$\mathrm{V} 1 \mathrm{~V} 2_{\mathrm{ZM} 109}-1 \mathrm{FD} 6$, were 149 and 37 for the IFA and alum groups, respectively (Fig. 3F).

Animals that were coprimed with DNA plus $\mathrm{V} 1 \mathrm{~V} 2 \mathrm{ZM}_{\mathrm{Z} 3}-2 \mathrm{~J} 9 \mathrm{C}$ scaffold protein and boosted with the homologous $\mathrm{V} 1 \mathrm{~V} 2{\mathrm{ZM} 53^{-}}^{-}$ 2J9C scaffold protein gave a better response than animals primed with DNA plus the V1V2 ${ }_{\mathrm{ZM} 53}-2 \mathrm{~J} 9 \mathrm{C}$ scaffold protein and boosted with the heterologous $\mathrm{V} 1 \mathrm{~V} 2_{\mathrm{A} 244}-2 \mathrm{~J} 9 \mathrm{C}$ scaffold protein (Fig. 3D). The $\mathrm{GMT}_{50}{ }^{-1}$ values for the homologous versus heterologous prime and boosting regimens were 149 and 22, respectively (Fig. 3F).

The V1V2 ${ }_{\mathrm{ZM} 53}-2 \mathrm{~F} 5 \mathrm{~K}$ protein immunogen gave a stronger response than the V1V2 $2_{\mathrm{ZM} 53}-2 \mathrm{~J} 9 \mathrm{C}$ immunogen, as shown in Fig. 3E. The $\mathrm{GMT}_{50}{ }^{-1}$ values for titration against $\mathrm{V} 1 \mathrm{~V} 2_{\mathrm{ZM} 109^{-}}-\mathrm{FD} 6$ for these two groups were 1,412 and 171, respectively (Fig. 3F).

Durability of the $\mathrm{Ab}$ response. To determine the durability of the immune response elicited with various immunogens and vaccine regimens, selected groups of rabbits were housed for up to 76 weeks and bled at various times after each immunization. The kinetics and the duration of the $\mathrm{Ab}$ responses against various antigens are shown for three groups of animals in Tables 4,5 , and 6 . When gp $120_{\mathrm{ZM} 109 \mathrm{~F}}$ DNA was used alone for the priming immunization, Abs reacted poorly with all antigens except gp120 ${ }_{\mathrm{ZM} 233}$ (Table 4, experimental group H1/5). After a boost with gp $120_{\mathrm{ZM} 109 \mathrm{~F}}$ protein, reactivity of gp $120_{\mathrm{ZM} 233}$-directed Abs increased and remained strong, and Abs to V1V2 $2_{\text {CaseA2 }}-\mathrm{gp} 70$ were significantly elevated although reactivity to other antigens remained weak. Antibody levels began to wane at week 21, which was 11 weeks after the last boost. In contrast, when DNA plus V1V2-scaffold immunogens were used for the three priming doses, followed by boosting with V1V2-scaffold proteins carrying the homologous or heterologous V1V2 regions in the epitope scaffold boosting immunogen (Tables 5 and 6, respectively), robust responses were generated against both V1V2 antigens and gp120 after the second or third priming dose. Antibody levels to the
V1V2-scaffold antigens increased after the protein boosts. Rabbits were maintained and bled periodically for the longest period of time in the experiment where rabbits received DNA plus $\mathrm{V} 1 \mathrm{~V} 2_{\mathrm{ZM} 53}-2 \mathrm{~J} 9 \mathrm{C}$ as the prime immunization and $\mathrm{V} 1 \mathrm{~V} 2_{\mathrm{ZM} 53}-2 \mathrm{~J} 9 \mathrm{C}$ for the boost (Table 5, experiment $\mathrm{H} 3 / 4$ ). The $\mathrm{Ab}$ response to V1V2 antigen constructs from clades $\mathrm{B}\left(\mathrm{V} 1 \mathrm{~V} 2_{\mathrm{YU} 2}-1 \mathrm{FD} 6\right)$ and $\mathrm{C}$ $\left(\mathrm{V} 1 \mathrm{~V} 2_{\mathrm{ZM} 109}-\mathrm{TTB}\right)$ were clearly enhanced by the protein boosts and were maintained at peak activity through weeks 26 to 36 , which corresponded to 16 to 26 weeks after the last protein boost; after that there was a very gradual decline. Ab responses were still detectable at week 76, which was 66 weeks after the last boost. As seen in Table 3, V1V2-specific Abs reacted most strongly when the V1V2 domain was held in a constrained position by the scaffold proteins (in this case $\mathrm{V} 1 \mathrm{~V} 2_{\mathrm{YU} 2}-1 \mathrm{FD} 6$ and $\mathrm{V} 1 \mathrm{~V} 2_{\mathrm{ZM} 109^{-T T B}}$ ) as opposed to antigens that harbored the V1V2 domain in an unconstrained configuration (gp120 ${ }_{\mathrm{ZM} 233}$ and V1V2 $2_{\mathrm{CaseA} 2}$-gp70).

The data in Tables 4, 5, and 6 also indicate that the Ab response is focused on V1V2. Antibodies reactive with a V3 consensus C peptide were induced, as expected, in the rabbits immunized with gp120 ${ }_{\text {ZM109 }}$ DNA and gp120 2 ZM109 protein (Table 4), but in animals primed with DNA gp120 2 Z109 plus V1V2 scaffolds and boosted with the V1V2 scaffolds, V3 Abs were detectable only at levels just above background and only during the immunization with the priming gp120 DNA (Tables 5 and 6). Further data are presented in Fig. 4 indicating that the Ab responses were focused on V1V2 to the exclusion of other gp120 epitopes. Here, the sera of animals primed with DNA and boosted with the V1V2-scaffold protein immunogen $\mathrm{V} 1 \mathrm{~V} 2_{\mathrm{ZM} 109^{-}} 1 \mathrm{FD} 6$ (Fig. 4A) or $\mathrm{V} 1 \mathrm{~V} 2_{\mathrm{ZM} 53^{-}}$ 2J9C (Fig. 4D) are shown to react after the boost with only $\mathrm{V} 1 \mathrm{~V} 2_{\mathrm{ZM} 109}-1 \mathrm{FD} 6$ and not with the $\mathrm{C} 5$ and $\mathrm{V} 3$ peptides, which are two of the most immunogenic epitopes in gp120 $(65,66)$. In contrast, several of the animals that were primed with DNA and boosted with the gp $120_{\mathrm{ZM} 109}$ protein reacted with either the $\mathrm{C} 5$ and/or the V3 peptide (Fig. $4 \mathrm{~B}$ and $\mathrm{C}$ ). Additionally, the data 
TABLE 5 Duration of antibody response during and after priming with DNA plus V1V2 $2_{\mathrm{ZM} 53}-2 \mathrm{~J} 9 \mathrm{C}$ and boosting with $\mathrm{V} 1 \mathrm{~V} 2_{\mathrm{ZM} 53}-2 \mathrm{~J} 9 \mathrm{C}$ (experimental group $\left.\mathrm{H} 3 / 4\right)^{a}$

\begin{tabular}{|c|c|c|c|c|c|c|c|}
\hline BLEED & Weeks & & $\begin{array}{l}\text { ZM233 } \\
\text { gp120 }\end{array}$ & $\begin{array}{c}\text { V1V2I } \\
\text { YU2-1FD6 }\end{array}$ & $\begin{array}{c}\text { V1V2I } \\
\text { ZM109-TTB }\end{array}$ & $\begin{array}{c}\text { V1V2/CaseA2- } \\
\text { gp70 }\end{array}$ & V3 ConsC \\
\hline I & 0 & Pre-bleed & 0.15 & 0.09 & 0.10 & 0.09 & 0.08 \\
\hline II & 2 & $2 w p 1 p$ & 0.62 & 0.13 & 0.14 & 0.09 & 0.13 \\
\hline III & 4 & $2 w p 2 p$ & 2.38 & 1.02 & 1.00 & 0.24 & 0.28 \\
\hline IV & 6 & $2 w p 3 p$ & 2.66 & 1.99 & 1.78 & 0.45 & 0.26 \\
\hline v & 12 & 2wp1b & 1.67 & 2.47 & 2.29 & 0.38 & 0.14 \\
\hline VI & 16 & $2 w p 2 b$ & 1.27 & 2.61 & 2.32 & 0.58 & 0.15 \\
\hline VII & 20 & $6 w p 2 b$ & 1.05 & 2.55 & 2.37 & 0.45 & 0.14 \\
\hline VIII & 26 & 12wp2b & 1.51 & 2.48 & 2.42 & 0.38 & 0.14 \\
\hline IX & 36 & $22 w p 2 b$ & 1.39 & 2.14 & 1.87 & 0.27 & 0.12 \\
\hline$x$ & 57 & $43 w p 2 b$ & 1.28 & 1.67 & 1.70 & 0.23 & 0.12 \\
\hline $\mathbf{X I}$ & 61 & $47 w p 2 b$ & 1.15 & 1.54 & 1.43 & 0.26 & 0.10 \\
\hline XII & 69 & $55 w p 2 b$ & 1.94 & 2.15 & 1.81 & 0.19 & 0.14 \\
\hline XIII & 76 & $62 w p 2 b$ & 1.63 & 1.93 & 1.79 & 0.19 & 0.14 \\
\hline
\end{tabular}

${ }^{a}$ Values are the mean ODs at $405 \mathrm{~nm}$ of five sera tested at 1:100. Data from 36 prebleed sera in various experiments were used to calculate a cutoff value (mean +3 standard deviations) of $\geq 0.14$. The results during priming are shown in bleeds I to IV, and those during and after boosts are represented in bleeds V to XIII (indicated by the black line). Abbreviations for the prime-boost regimen use the following form: 2 wplp, 2 weeks post-1st prime; 2 wplb, 2 weeks post-1st boost. V3 ConsC, V3 consensus C peptide.

shown in Fig. 4 indicate that the gp120 DNA priming induced only weak $\mathrm{Ab}$ responses, and these responses were against $\mathrm{C} 5, \mathrm{~V} 1 \mathrm{~V} 2$, and/or V3. The subsequent protein boost was responsible for the induction of the strong $\mathrm{Ab}$ responses, and in the case of the ani- mals receiving the V1V2-scaffold protein immunogens, the prime-induced weak responses to C5 and V3 had waned completely (Fig. 4A and D). Thus, Ab responses induced by the rationally designed V1V2-scaffold protein immunogens focused the

TABLE 6 Duration of the antibody response during and after priming with DNA $+\mathrm{V} 1 \mathrm{~V} 2_{\mathrm{ZM} 53}-2 \mathrm{~J} 9 \mathrm{C}$ and boosting with $\mathrm{V} 1 \mathrm{~V} 2_{\mathrm{A} 244^{-}} \mathrm{J} 9 \mathrm{C}(\text { experimental group } \mathrm{H} 4 / 4)^{a}$

\begin{tabular}{|c|c|c|c|c|c|c|c|}
\hline BLEED & Weeks & & $\begin{array}{l}\text { ZM233 } \\
\text { gp120 }\end{array}$ & $\begin{array}{l}\text { V1V2I } \\
\text { YU2- } \\
\text { 1FD6 }\end{array}$ & $\begin{array}{c}\text { V1V2I } \\
\text { ZM109-TTB }\end{array}$ & $\begin{array}{c}\text { V1V2/Case A2- } \\
\text { gp70 }\end{array}$ & V3 ConsC \\
\hline I & 0 & Pre-bleed & 0.13 & 0.09 & 0.09 & 0.09 & 0.09 \\
\hline II & 10 & $2 w p 3 p$ & 2.00 & 2.51 & 2.4 & 0.56 & 0.15 \\
\hline III & 16 & 2wp1b & 1.38 & 2.15 & 2.29 & 0.39 & 0.11 \\
\hline IV & 20 & $2 w p 2 b$ & 1.19 & 1.66 & 2.49 & 0.40 & 0.11 \\
\hline V & 22 & $4 w p 2 b$ & 1.20 & 1.72 & 2.48 & 0.42 & 0.10 \\
\hline VI & 24 & $6 w p 2 b$ & 1.08 & 1.38 & 2.63 & 0.39 & 0.11 \\
\hline VII & 35 & $17 w p 2 b$ & 1.07 & 0.73 & 2.16 & 0.24 & 0.10 \\
\hline VIII & 42 & $24 w p 2 b$ & 1.33 & 0.81 & 2.48 & 0.34 & 0.12 \\
\hline IX & 50 & $32 w p 2 b$ & 1.45 & 0.55 & 2.26 & 0.23 & 0.10 \\
\hline
\end{tabular}

${ }^{a}$ Values are the mean ODs at $405 \mathrm{~nm}$ of five sera tested at 1:100. Data from 36 prebleed sera in various experiments were used to calculate a cutoff value (mean +3 standard deviations) of $\geq 0.14$. The results during priming are shown in bleeds I and II, and those during and after boosts are represented in bleeds III to IX (indicated by the black line). Abbreviations for the prime-boost regimen use the following form: 2 wplp, 2 weeks post-1st prime; 2 wplb, 2 weeks post-1st boost. V3 ConsC, V3 consensus C peptide. 
(A)

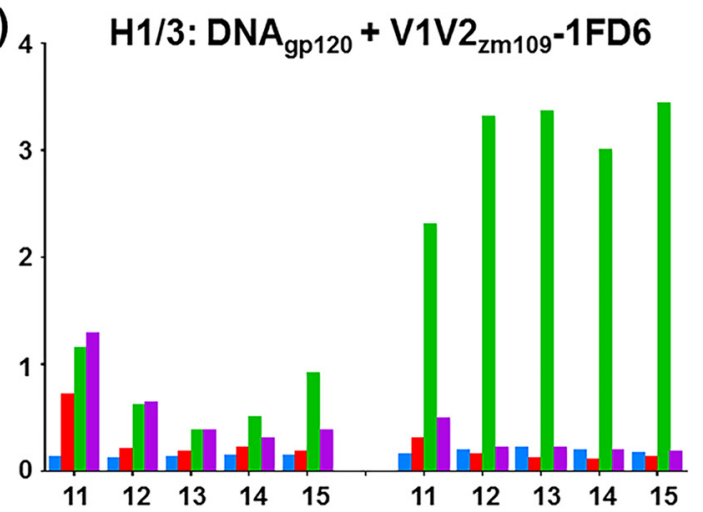

(C)

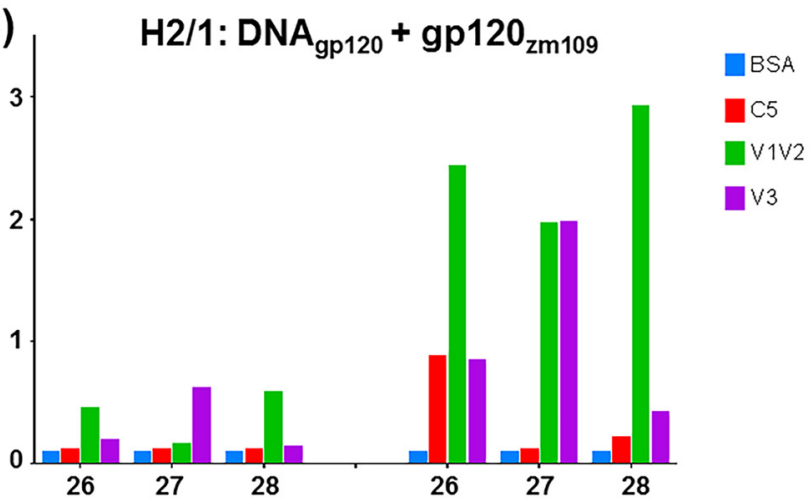

(B)
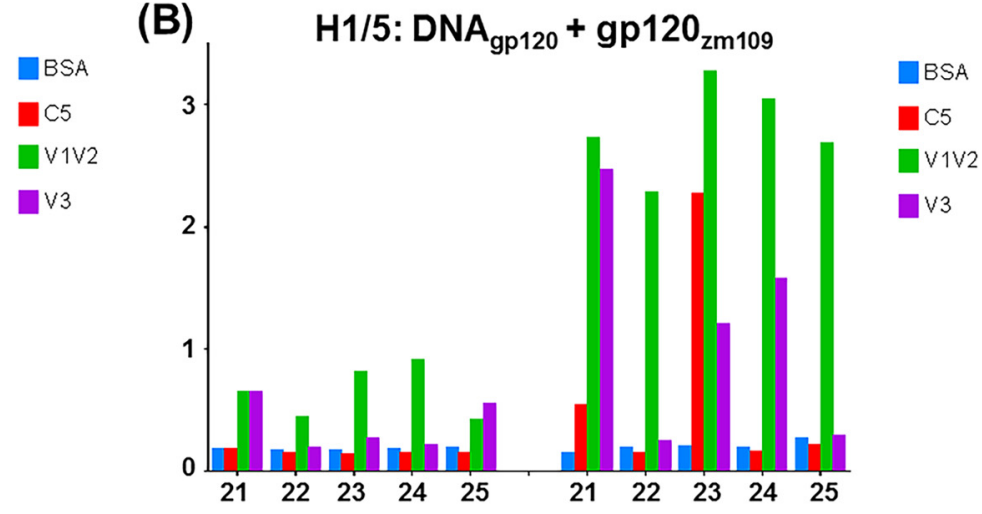

(D)

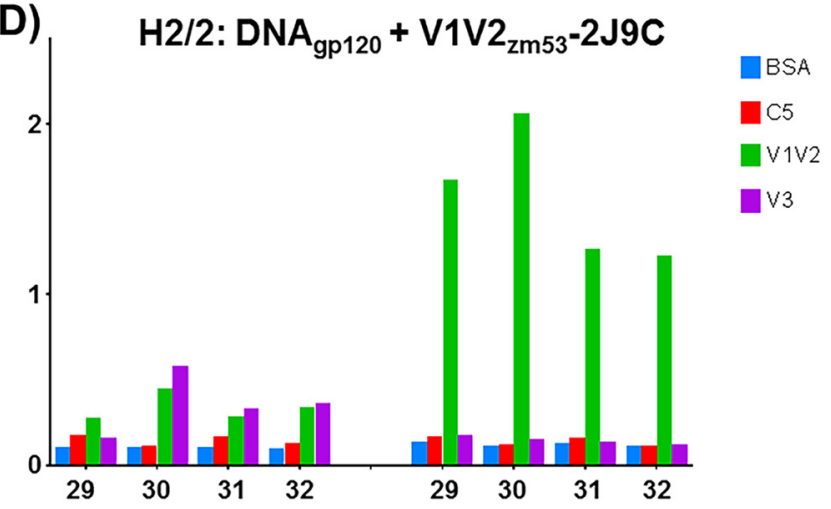

FIG 4 Specificity of the Ab response. The average OD values of replicates from ELISAs are shown on the $y$ axis for sera from individual animals tested for reactivity against BSA, C5 peptide, $\mathrm{V} 1 \mathrm{~V} 2_{\mathrm{ZM} 109}-1 \mathrm{FD} 6$, and a consensus $\mathrm{CV} 3$ peptide. The responses are shown for sera diluted 1:100 from each animal (numbered on the $x$ axis). The left half of each graph shows the results with sera collected 2 weeks after the third priming immunization. The right half of each graph shows the responses obtained with sera collected 2 weeks after the second boost.

Ab response on the V1V2 region to the exclusion of other Env antigens.

Biologic function of Abs induced by V2-targeting vaccines. V2i-specific MAbs have little to no neutralizing activity (59), and while there was a correlation between reduced risk of infection in RV144 vaccinees and the level of V1V2 binding Abs, there was no correlation with serum neutralizing activity (15). Thus, we did not expect the immune sera from the rabbits immunized in these studies to display neutralizing activity. To test for neutralizing activity of immune rabbit sera, a modified, more sensitive version of the TZM.bl assay was used (67) in which virus and sera were incubated together for $24 \mathrm{~h}$ prior to application to cells. Indeed, there was no neutralizing activity when sera from the five animals in one of the best groups (H3/4; primed with gp $120_{\mathrm{ZM} 109 \mathrm{~F}} \mathrm{DNA}$ plus $\mathrm{V} 1 \mathrm{~V} 2_{\mathrm{ZM} 53}-2 \mathrm{~J} 9 \mathrm{C}$ and boosted with $\left.\mathrm{V} 1 \mathrm{~V} 2_{\mathrm{ZM} 53}-2 \mathrm{~J} 9 \mathrm{C}\right)$ were tested against BaL.26, YU2, and SF162 (data not shown).

Since increasing attention has been focused on Fc-dependent $\mathrm{Ab}$ functions, we chose to test the ability of the serum Abs from immunized rabbits to mediate phagocytosis $(12,18,24,38)$. We used the assay that was first described by Ackerman et al. (48) to assess the phagocytic activity of THP-1 cells incubated with various HIV Env-specific human MAbs bound to beads coated with biotinylated gp120 $\mathrm{ZM}_{33}$. Figure $5 \mathrm{~A}$ shows the Ab-dependent cellular phagocytosis (ADCP) scores generated using the optimized assay described in the Materials and Methods section. Robust phagocytosis was achieved with beads coated with gp $120_{\mathrm{ZM} 53}$ and then bound to V2i MAb $830 \mathrm{~A}$ or 697 or to the V3-specific MAb
3869. This activity is shown to be Fc dependent, as illustrated by the ability of cytochalasin D and human Fc receptor blocking reagent (Fig. 5, Fcblock) to inhibit phagocytosis. The V2p-specific MAb CH58 was also shown to be capable of mediating ADCP of beads coated with the $\mathrm{cV} 2$ peptide. This optimized assay was next used to test the phagocytic activity of serum from each rabbit in several groups of immunized animals. Immune sera were each titrated from a dilution of 1:6 to $1: 486$ for phagocytic activity against beads coated with $\mathrm{V} 1 \mathrm{~V} 22_{\mathrm{ZM} 109}-1 \mathrm{FD} 6$, and the mean ADCP score for each group of rabbits at each of five serum dilutions is plotted in Fig. 5B. Similar levels of phagocytic activity were detected in sera from rabbits in three of the six groups tested: H3/1 (primed with gp120 DNA and boosted with V1V2 ${ }_{\mathrm{ZM} 53}-2 \mathrm{~F} 5 \mathrm{~K}$ ), $\mathrm{H} 3 / 4$ (primed with gp120 DNA plus V1V2 ${ }_{\mathrm{ZM} 53}-2 \mathrm{~J} 9 \mathrm{C}$ protein and boosted with $\mathrm{V} 1 \mathrm{~V} 2_{\mathrm{ZM} 53}-2 \mathrm{~J} 9 \mathrm{C}$ ), and $\mathrm{H} 4 / 4$ (primed with gp120 DNA plus $\mathrm{V} 1 \mathrm{~V} 2_{\mathrm{ZM} 53}-2 \mathrm{~J} 9 \mathrm{C}$ protein and boosted with $\mathrm{V} 1 \mathrm{~V} 2_{\mathrm{A} 244^{-}}$ 2J9C). In contrast, little or no activity was detected in sera from animals in H1/5 (primed with gp120 DNA and boosted with gp120 protein), H2/4 (primed with DNA and boosted with $\mathrm{V} 1 \mathrm{~V} 2_{\mathrm{ZM} 109}-1 \mathrm{FD} 6-\mathrm{Fc}$ ), and H2/5 (primed with DNA and boosted with V1V2 $\left.2_{\mathrm{ZM} 109}-\mathrm{TTB}\right)$. A similar pattern was found for sera tested at a dilution of 1:20 derived from the same six groups of animals and tested using beads coated with $\mathrm{V} 1 \mathrm{~V} 2_{\mathrm{YU} 2}-1 \mathrm{FD} 6$ (Fig. $5 \mathrm{C}$ ). It is particularly striking that boosting with gp120 protein does not induce Abs with phagocytic activity (group H1/5) while three groups boosted with $\mathrm{V} 1 \mathrm{~V} 2_{\mathrm{ZM} 53}-2 \mathrm{~F} 5 \mathrm{~K}, \mathrm{~V} 1 \mathrm{~V} 2_{\mathrm{ZM} 53}-2 \mathrm{~J} 9 \mathrm{C}$, or $\mathrm{V} 1 \mathrm{~V} 2_{\mathrm{A} 244}-2 \mathrm{~J} 9 \mathrm{C}$ displayed strong activity in this assay; this denotes 

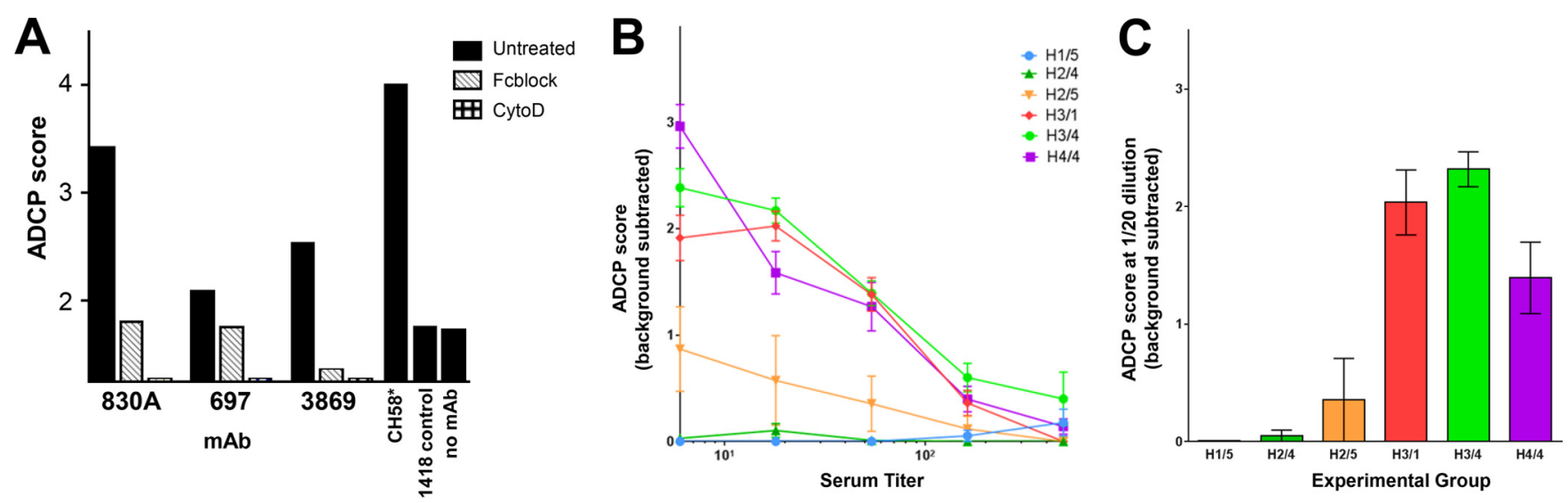

\begin{tabular}{|c|c|c|c|c|c|c|}
\hline \multirow{2}{*}{$\begin{array}{c}\text { Expt/ } \\
\text { Group }\end{array}$} & \multicolumn{3}{|c|}{ Prime } & \multicolumn{2}{c|}{ Boost } & \multirow{2}{*}{ OD vs. V1V2 ZM109-1FD6 } \\
\cline { 2 - 6 } & DNA & V1V2 & Scaffold & V1V2 & Scaffold & \\
\hline H1/5 & ZM109-opt gp120 & - & - & \multicolumn{2}{|c|}{ ZM109 gp120 } & 2.4 \\
\hline H2/4 & ZM109-opt gp120 & - & - & ZM109 & 1FD6-Fc & 2.8 \\
\hline H2/5 & ZM109-opt gp120 & - & - & ZM109 & TTB & 1.8 \\
\hline H3/1 & ZM109-opt gp120 & - & - & ZM53 & 2F5K & 3.4 \\
\hline H3/4 & ZM109-opt gp120 & ZM53 & 2J9C & ZM53 & 2J9C & 3.5 \\
\hline H4/4 & ZM109-opt gp120 & ZM53 & 2J9C & A244 & 2J9C & 2.5 \\
\hline
\end{tabular}

FIG 5 Phagocytosis assay with monoclonal antibodies (MAbs) and rabbit immune sera. The ADCP assay was performed and reported as ADCP scores as described in Materials and Methods. (A) Beads were coated with either gp120 ${ }_{\mathrm{ZM} 53}$ and then incubated with the designated MAb (V2i-specific MAb $830 \mathrm{~A}$ or 697 or V3-specific MAb 3869) or with cV2 peptide and incubated with V2p-specific MAb CH58. Cells that had been preincubated for 30 min at $37^{\circ} \mathrm{C}$ with either 30 $\mu \mathrm{l}$ of FcR blocking agent (Fcblock; Miltenyi Biotec) or $10 \mu \mathrm{l}$ of $10 \mu \mathrm{g} / \mathrm{ml}$ cytochalasin D (CytoD; Sigma) or were untreated and then added to the bead-MAb

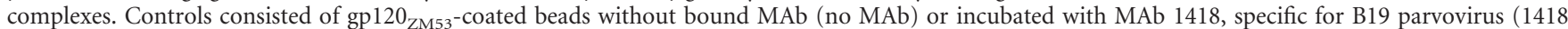
control). (B) Titration of phagocytic activity in rabbit immune sera using beads coated with V1V2 ${ }_{\mathrm{ZM} 109}-1$ FD6. Data shown are the means of values from individual rabbits in each group \pm standard errors of the means. (C) ADCP scores for rabbit immune sera diluted 1:20 when beads coated with V1V2 $2_{\mathrm{YU} 2}-1 \mathrm{FD} 6$ were used. Data shown are the means from individual rabbits in each group \pm standard errors of the means. (D) Immunization regimen used for each of the six rabbit groups studied and the mean OD determined from ELISAs with a 1:100 dilution of serum from each individual rabbit in each group tested for reactivity with $\mathrm{V} 1 \mathrm{~V} 2_{\mathrm{ZM} 109^{-}}-1 \mathrm{FD} 6$.

a significant qualitative difference in the Abs induced by trimeric V1V2-scaffold immunogens as opposed to gp120 protein, dimeric immunogens, or pentameric immunogens. It is noteworthy that there is no correlation between phagocytic activity with $\mathrm{V} 1 \mathrm{~V} 2_{\mathrm{ZM} 109}-1 \mathrm{FD} 6$-coated beads and Ab reactivity of the same serum in ELISAs against $\mathrm{V} 1 \mathrm{~V} 2_{\mathrm{ZM} 109}-1 \mathrm{FD} 6$ (Fig. $5 \mathrm{~B}$ and $\mathrm{D}$ ). These data are not contradictory in that phagocytosis is a function of an Fc-mediated activity (as shown in Fig. 5A) while ELISA reactivity reflects binding of Abs to the antigen via the Fab fragment.

\section{DISCUSSION}

The experiments described here were designed to focus a vaccineinduced $\mathrm{Ab}$ response on the V1V2 region of the HIV-1 gp120 envelope glycoprotein since Abs to this region have been associated with reduced rates of HIV and SIV infection $(12,13,18,28$, $30,31,32,33,34,68)$. The results show that when different immunization regimens employing gp120 DNA and various V1V2 protein scaffold immunogens were used, the V1V2 region was targeted by the Ab response, with little or no induction of Abs to other Env epitopes. The response was durable, with Abs detectable for $\geq 1$ year after the last immunization. The vaccine-induced Abs were (i) highly cross-reactive with the V1V2 regions and gp120 molecules derived from diverse strains and clades, (ii) directed at linear and conformational epitopes in V2, and (iii) able to mediate phagocytosis, a function that has been correlated with protection from HIV, SIV, and SHIV as well as other viral diseases (12, 18, 24, 38). The specificities of the vaccine-induced rabbit Abs were similar to those of human-derived V2i-specific MAbs on the basis of their ELISA reactivities with various V1V2-scaffold immunogens (Table 3 and Fig. 1), their inability to neutralize viruses, and their ability to mediate Fc-dependent phagocytosis (Fig. 5).

The rationale for using an epitope-specific approach to vaccine design was based on studies in the literature indicating that targeting specific epitopes of infectious organisms could protect against infection by various pathogens, an approach termed reverse vaccinology (69). For example, targeting the factor H-binding protein of Neisseria meningitides with an experimental vaccine prevented meningococcal meningitis and sepsis in mice (70), and targeting the site $\varnothing$ of the fusion glycoprotein of respiratory syncytial virus (RSV) elicited high levels of RSV-specific Abs with neutralizing activity (71). Moreover, focusing the immune response on the V3 region of HIV gp 120 with V3-scaffold immunogens induced cross-clade neutralizing Abs and recapitulated the binding and biologic activity of V3-specific human MAbs $(35,36)$. 
Here, we describe a successful reverse vaccinology approach using immunogens that target the V1V2 portion of gp120. This study and the successful reverse vaccinology studies cited above stand in marked contrast to several unsuccessful attempts to use epitope scaffold immunogens to elicit polyclonal responses designed to recapitulate the specificity and function of broadly neutralizing MAbs that target HIV sites of vulnerability (72-76).

It has been suggested that nonneutralizing mechanisms, such as phagocytosis, neutrophil activation, and ADCC, are likely to play a role in both HIV prevention and reservoir-eliminating therapeutic approaches $(77,78)$. This is supported by the RV144 clinical trial where a correlate of reduced infection was found with various Fc-mediated activities but not with neutralization (9-18). In addition, a myriad of studies have shown an association between $\mathrm{Fc} \gamma$-dependent $\mathrm{Ab}$ functions and reduced infection with SIV and SHIV $(22,24,32,33,38)$.

The mechanism by which Abs mediate various Fc-dependent antiviral functions is the subject of ongoing studies. The protective role of HIV Abs in binding to $\mathrm{Fc}$ receptors was established in passive immunization experiments (79). In addition, the nature of Fc-glycan structures was shown to selectively promote Fc-effector functions independent of Ab specificity for HIV epitopes, and particular Ab glycan structures were associated with enhanced ADCC as well as ADCP activity (80). Further studies have indicated that $\mathrm{Fc} \gamma$ receptor-mediated activity is associated with preferential engagement of activating, but not inhibitory, Fc $\gamma$ receptors (81). Thus, biologic functions of nonneutralizing Abs are affected by many factors, including isotype, subtype, affinity for $\mathrm{Fc}$ receptors, and ability to activate complement-all of which are functions of the Fc rather than the Fab fragment of immunoglobulins (82). It is notable, therefore, that in targeting the immune response to V1V2, we have induced Abs that, as expected on the basis of previous data (59), have no neutralizing activity but mediate ADCP. Notably, there was no phagocytic activity in the sera of rabbits immunized with gp120 DNA and gp120 protein (experimental group $\mathrm{H1} / 5$ ) whereas the immune sera we tested from animals immunized with selected gp120 DNA and V1V2-scaffold proteins (experimental groups $\mathrm{H} 3 / 1, \mathrm{H} 3 / 4$, and $\mathrm{H} 4 / 4$ ) displayed this activity (Fig. 5), indicating that there was a qualitative difference between the immune responses induced by gp 120 and those induced by V1V2-scaffold immunogens.

The induction of ADCP by immunogens V1V2-2F5K and V1V2-2J9C, in contrast to the failure to induce ADCP with gp120 protein, may bear on the differing conformations of these antigens. V1V2 is presented by the $2 \mathrm{~F} 5 \mathrm{~K}$ and $2 \mathrm{~J} 9 \mathrm{C}$ scaffolds as an apical trimeric structure whose conformation is constrained by their insertion in these scaffolds (47). In contrast, the V1V2 region in gp120 is presented as a monomeric, unconstrained domain. The V1V2-2J9C design was based on the V1V2 structure as observed in complex with V2q MAb PG9 (49), while the V1V2-2F5K design was based on the V1V2 structure in complex with V2i MAb $830 \mathrm{~A}$ (37). The geometry of the trimeric configuration (position and orientation with respect to the trimer axis) of the V1V2 domains in both designs was guided by the low-resolution cryoelectron microscopy (EM) structure of the SOSIP trimeric spike in complex with MAb PG9 (53) before the higher-resolution structure became available (54).

In summary, we have used the structure of V1V2 epitopes recognized by various human MAbs that target the V1V2 region of gp120 to design V1V2-scaffold immunogens which induced Abs in rabbits that recapitulated the specificity and functional activity of human V2i MAbs. The vaccine-induced rabbit serum Abs were focused on the V1V2 region, were cross-clade reactive, mediated Ab-dependent phagocytosis, and were detectable $\geq 1$ year after the last immunizing dose. The data demonstrate the success of a reverse vaccinology approach to HIV vaccine design and the potential for specifically targeting sites of vulnerability with rationally designed immunogens.

\section{FUNDING INFORMATION}

This work, including the efforts of Susan B. Zolla-Pazner, Rebecca Powell, Sara Yahyaei, Constance Williams, Xunqing Jiang, Wei Li, Shan Lu, Shixia Wang, Chitra Upadhyay, Catarina E. Hioe, Maxim Totrov, and XiangPeng Kong, was funded by HHS | National Institutes of Health (NIH) (P01 AI100151). This work, including the efforts of Susan B. Zolla-Pazner and Catarina E. Hioe, was funded by Icahn School of Medicine at Mount Sinai (ISMMS).

\section{REFERENCES}

1. Excler JL, Ake J, Robb ML, Kim JH, Plotkin SA. 2014. Nonneutralizing functional antibodies: a new "old” paradigm for HIV vaccines. Clin Vaccine Immunol 21:1023-1036. http://dx.doi.org/10.1128/CVI.00230-14.

2. Schmaljohn A. 2013. Protective antiviral antibodies that lack neutralizing activity. Curr HIV Res 11:345-353. http://dx.doi.org/10.2174 /1570162X113116660057.

3. Holl V, Peressin M, Moog C. 2009. Antibody-mediated Fcy receptorbased mechanisms of HIV inhibition: recent findings and new vaccination strategies. Viruses 1:1265-1294. http://dx.doi.org/10.3390/v1031265.

4. Balachandran N, Bacchetti S, Rawls WE. 1982. Protection against lethal challenge of BALB/c mice by passive transfer of monoclonal antibodies to five glycoproteins of herpes simplex virus type 2. Infect Immun 37:11321137.

5. Gorander S, Ekblad M, Bergstrom T, Liljeqvist JA. 2014. Anti-glycoprotein $\mathrm{g}$ antibodies of herpes simplex virus 2 contribute to complete protection after vaccination in mice and induce antibody-dependent cellular cytotoxicity and complement-mediated cytolysis. Viruses 6:4358-4372. http: //dx.doi.org/10.3390/v6114358.

6. Petro C, Gonzalez PA, Cheshenko N, Jandl T, Khajoueinejad N, Benard A, Sengupta M, Herold BC, Jacobs WR. 2015. Herpes simplex type 2 virus deleted in glycoprotein $\mathrm{D}$ protects against vaginal, skin and neural disease. eLife 4:e06054.

7. DiLillo DJ, Tan GS, Palese P, Ravetch JV. 2014. Broadly neutralizing hemagglutinin stalk-specific antibodies require Fc $\gamma \mathrm{R}$ interactions for protection against influenza virus in vivo. Nat Med 20:143-151. http://dx.doi .org/10.1038/nm.3443.

8. Henry Dunand CJ, Leon PE, Huang M, Choi A, Chromikova V, Ho IY, Tan GS, Cruz J, Hirsh A, Zheng NY, Mullarkey CE, Ennis FA, Terajima M, Treanor JJ, Topham DJ, Subbarao K, Palese P, Krammer F, Wilson PC. 2016. Both neutralizing and non-neutralizing human H7N9 influenza vaccine-induced monoclonal antibodies confer protection. Cell Host Microbe 19:800-813. http://dx.doi.org/10.1016/j.chom.2016.05.014.

9. Corey L, Gilbert PB, Tomaras GD, Haynes BF, Pantaleo G, Fauci AS. 2015. Immune correlates of vaccine protection against HIV-1 acquisition. Sci Transl Med 7:310rv7. http://dx.doi.org/10.1126/scitranslmed.aac7732.

10. Li SS, Gilbert PB, Tomaras GD, Kijak G, Ferrari G, Thomas R, Pyo CW, Zolla-Pazner S, Montefiori D, Liao HX, Nabel G, Pinter A, Evans DT, Gottardo R, Dai JY, Janes H, Morris D, Fong Y, Edlefsen PT, Li F, Frahm N, Alpert MD, Prentice H, Rerks-Ngarm S, Pitisuttithum P, Kaewkungwal J, Nitayaphan S, Robb ML, O'Connell RJ, Haynes BF, Michael NL, Kim JH, McElrath MJ, Geraghty DE. 2014. FCGR2C polymorphisms associate with HIV-1 vaccine protection in RV144 trial. J Clin Invest 124:3879-3890. http://dx.doi.org/10.1172/JCI75539.

11. Pollara J, Bonsignori M, Moody MA, Liu P, Alam SM, Hwang K-K, Gurley TC, Kozink DM, Armand LC, Marshall DJ, Whitesides JF, Kaewkungwal J, Nitayaphan S, Pitisuttithum P, Rerks-Ngarm S, Robb ML, O’Connell RJ, Kim JH, Michael NL, Montefiori DC, Tomaras GD, Liao H-X, Haynes BF, Ferrari G. 2014. HIV-1 vaccine-induced C1 and V2 Env-specific antibodies synergize for increased antiviral activities. J Virol 88:7715-7726. http://dx.doi.org/10.1128/JVI.00156-14.

12. Chung AW, Ghebremichael M, Robinson H, Brown E, Choi I, Lane S, 
Dugast AS, Schoen MK, Rolland M, Suscovich TJ, Mahan AE, Liao L, Streeck H, Andrews C, Rerks-Ngarm S, Nitayaphan S, de Souza MS, Kaewkungwal J, Pitisuttithum P, Francis D, Michael NL, Kim JH, Bailey-Kellogg C, Ackerman ME, Alter G. 2014. Polyfunctional Fceffector profiles mediated by IgG subclass selection distinguish RV144 and VAX003 vaccines. Sci Transl Med 6:228ra38. http://dx.doi.org/10.1126 Iscitranslmed.3007736.

13. Haynes BF, Gilbert PB, McElrath MJ, Zolla-Pazner S, Tomaras GD, Alam SM, Evans DT, Montefiori DC, Karnasuta C, Sutthent R, Liao H-X, DeVico AL, Lewis GK, Williams C, Pinter A, Fong Y, Janes H, DeCamp A, Huang Y, Rao M, Billings E, Karasavvas N, Robb ML, Ngauy V, de Souza MS, Paris R, Ferrari G, Bailer RT, Soderberg KA, Andrews C, Berman PW, Frahm N, De Rosa SC, Alpert MD, Yates NL, Shen X, Koup RA, Pitisuttithum P, Kaewkungwal J, Nitayaphan S, Rerks-Ngarm S, Michael NL, Kim JH. 2012. Immune correlates analysis of the ALVAC-AIDSVAX HIV-1 vaccine efficacy trial. N Engl J Med 366: 1275-1286. http://dx.doi.org/10.1056/NEJMoa1113425.

14. Bonsignori M, Pollara J, Moody MA, Alpert MD, Chen X, Hwang KK, Gilbert PB, Huang Y, Gurley TC, Kozink DM, Marshall DJ, Whitesides JF, Tsao CY, Kaewkungwal J, Nitayaphan S, Pitisuttithum P, RerksNgarm S, Kim JH, Michael NL, Tomaras GD, Montefiori DC, Lewis GK, DeVico A, Evans DT, Ferrari G, Liao HX, Haynes BF. 2012. Antibody-dependent cellular cytotoxicity-mediating antibodies from an HIV-1 vaccine efficacy trial target multiple epitopes and preferentially use the VH1 gene family. J Virol 86:11521-11532. http://dx.doi.org/10.1128 /JVI.01023-12.

15. Montefiori DC, Karnasuta C, Huang Y, Ahmed H, Gilbert P, de Souza MS, McLinden R, Tovanabutra S, Laurence-Chenine A, Sanders-Buell E, Moody MA, Bonsignori M, Ochsenbauer C, Kappes J, Tang H, Greene K, Gao H, LaBranche CC, Andrews C, Polonis VR, RerksNgarm S, Pitisuttithum P, Nitayaphan S, Kaewkungwal J, Self SG, Berman PW, Francis D, Sinangil F, Lee C, Tartaglia J, Robb ML, Haynes BF, Michael NL, Kim JH. 2012. Magnitude and breadth of the neutralizing antibody response in the RV144 and Vax003 HIV-1 vaccine efficacy trials. J Infect Dis 206:431-441. http://dx.doi.org/10.1093/infdis /jis367.

16. Liao H-X, Bonsignori M, Alam SM, McLellan Jason S, Tomaras Georgia D, Moody MA, Kozink Daniel M, Hwang K-K, Chen X, Tsao C-Y, Liu P, Lu X, Parks Robert J, Montefiori David C, Ferrari G, Pollara J, Rao M, Peachman Kristina K, Santra S, Letvin Norman L, Karasavvas N, Yang Z-Y, Dai K, Pancera M, Gorman J, Wiehe K, Nicely Nathan I, Rerks-Ngarm S, Nitayaphan S, Kaewkungwal J, Pitisuttithum P, Tartaglia J, Sinangil F, Kim Jerome H, Michael Nelson L, Kepler Thomas B, Kwong Peter D, Mascola John R, Nabel Gary J, Pinter A, Zolla-Pazner S, Haynes Barton F. 2013. Vaccine induction of antibodies against a structurally heterogeneous site of immune pressure within HIV-1 envelope protein variable regions 1 and 2 . Immunity 38:176-186. http://dx.doi .org/10.1016/j.immuni.2012.11.011.

17. Pollara J, Bonsignori M, Moody MA, Pazgier M, Haynes BF, Ferrari G. 2013. Epitope specificity of human immunodeficiency virus- 1 antibody dependent cellular cytotoxicity [ADCC] responses. Curr HIV Res 11:378387. http://dx.doi.org/10.2174/1570162X113116660059.

18. Chung AW, Kumar MP, Arnold KB, Yu WH, Schoen MK, Dunphy LJ, Suscovich TJ, Frahm N, Linde C, Mahan AE, Hoffner M, Streeck H, Ackerman ME, McElrath MJ, Schuitemaker H, Pau MG, Baden LR, Kim JH, Michael NL, Barouch DH, Lauffenburger DA, Alter G. 2015. Dissecting polyclonal vaccine-induced humoral immunity against HIV using systems serology. Cell 163:988-998. http://dx.doi.org/10.1016/j.cell 2015.10.027.

19. Patterson LJ, Malkevitch N, Venzon D, Pinczewski J, Gomez-Roman VR, Wang L, Kalyanaraman VS, Markham PD, Robey FA, RobertGuroff M. 2004. Protection against mucosal simian immunodeficiency virus SIV $_{\text {mac251 }}$ challenge by using replicating adenovirus-SIV multigene vaccine priming and subunit boosting. J Virol 78:2212-2221. http://dx.doi .org/10.1128/JVI.78.5.2212-2221.2004.

20. Gomez-Roman VR, Patterson LJ, Venzon D, Liewehr D, Aldrich K, Florese R, Robert-Guroff M. 2005. Vaccine-elicited antibodies mediate antibody-dependent cellular cytotoxicity correlated with significantly reduced acute viremia in rhesus macaques challenged with SIVmac251. J Immunol 174:2185-2189. http://dx.doi.org/10.4049 /jimmunol.174.4.2185.

21. Forthal DN, Moog C. 2009. Fc receptor-mediated antiviral antibodies.
Curr Opin HIV AIDS 4:388-393. http://dx.doi.org/10.1097/COH .0b013e32832f0a89.

22. Alpert MD, Harvey JD, Lauer WA, Reeves RK, Piatak M, Jr, Carville A, Mansfield KG, Lifson JD, Li W, Desrosiers RC, Johnson RP, Evans DT. 2012. ADCC develops over time during persistent infection with liveattenuated SIV and is associated with complete protection against SIV $_{\text {mac }} 251$ challenge. PLoS Pathog 8:e1002890. http://dx.doi.org/10.1371 /journal.ppat.1002890.

23. Fouts TR, Bagley K, Prado IJ, Bobb KL, Schwartz JA, Xu R, Zagursky RJ, Egan MA, Eldridge JH, LaBranche CC, Montefiori DC, Le Buanec H, Zagury D, Pal R, Pavlakis GN, Felber BK, Franchini G, Gordon S, Vaccari M, Lewis GK, DeVico AL, Gallo RC. 2015. Balance of cellular and humoral immunity determines the level of protection by HIV vaccines in rhesus macaque models of HIV infection. Proc Natl Acad Sci U S A 112:E992-E999. http://dx.doi.org/10.1073/pnas.1423669112.

24. Barouch DH, Stephenson KE, Borducchi EN, Smith K, Stanley K, McNally AG, Liu J, Abbink P, Maxfield LF, Seaman MS, Dugast AS, Alter G, Ferguson M, Li W, Earl PL, Moss B, Giorgi EE, Szinger JJ, Eller LA, Billings EA, Rao M, Tovanabutra S, Sanders-Buell E, Weijtens M, Pau MG, Schuitemaker H, Robb ML, Kim JH, Korber BT, Michael NL. 2013. Protective efficacy of a global HIV-1 mosaic vaccine against heterologous SHIV challenges in rhesus monkeys. Cell 155:531-539. http://dx .doi.org/10.1016/j.cell.2013.09.061.

25. Vargas-Inchaustegui DA, Robert-Guroff M. 2013. Fc receptor-mediated immune responses: new tools but increased complexity in HIV prevention. Curr HIV Res 11:407-420. http://dx.doi.org/10.2174/1570162X113 116660063.

26. Santra S, Tomaras GD, Warrier R, Nicely NI, Liao HX, Pollara J, Liu P, Alam SM, Zhang R, Cocklin SL, Shen X, Duffy R, Xia SM, Schutte RJ, Pemble Iv CW, Dennison SM, Li H, Chao A, Vidnovic K, Evans A, Klein K, Kumar A, Robinson J, Landucci G, Forthal DN, Montefiori DC, Kaewkungwal J, Nitayaphan S, Pitisuttithum P, Rerks-Ngarm S, Robb ML, Michael NL, Kim JH, Soderberg KA, Giorgi EE, Blair L, Korber BT, Moog C, Shattock RJ, Letvin NL, Schmitz JE, Moody MA, Gao F, Ferrari G, Shaw GM, Haynes BF. 2015. Human non-neutralizing HIV-1 envelope monoclonal antibodies limit the number of founder viruses during SHIV mucosal infection in rhesus macaques. PLoS Pathog 11:e1005042. http://dx.doi.org/10.1371/journal.ppat.1005042.

27. Mabuka J, Nduati R, Odem-Davis K, Peterson D, Overbaugh J. 2012. HIV-specific antibodies capable of ADCC are common in breastmilk and are associated with reduced risk of transmission in women with high viral loads. PLoS Pathog 8:e1002739. http://dx.doi.org/10.1371/journal.ppat .1002739 .

28. Zolla-Pazner S, deCamp AC, Cardozo T, Karasavvas N, Gottardo R, Williams C, Morris DE, Tomaras G, Rao M, Billings E, Berman P, Shen $\mathrm{X}$, Andrews C, O'Connell RJ, Ngauy V, Nitayaphan S, de Souza M, Korber B, Koup R, Bailer RT, Mascola JR, Pinter A, Montefiori D, Haynes BF, Robb ML, Rerks-Ngarm S, Michael NL, Gilbert PB, Kim JH. 2013. Analysis of V2 antibody responses induced in vaccinees in the ALVAC/AIDSVAX HIV-1 vaccine efficacy trial. PLoS One 8:e53629. http: //dx.doi.org/10.1371/journal.pone.0053629.

29. Gottardo R, Bailer RT, Korber BT, Gnanakaran S, Phillips J, Shen X, Tomaras GD, Turk E, Imholte G, Eckler L, Wenschuh H, Zerweck J, Greene K, Gao H, Berman PW, Francis D, Sinangil F, Lee C, Nitayaphan S, Rerks-Ngarm S, Kaewkungwal J, Pitisuttithum P, Tartaglia J, Robb ML, Michael NL, Kim JH, Zolla-Pazner S, Haynes BF, Mascola JR, Self S, Gilbert P, Montefiori DC. 2013. Plasma IgG to linear epitopes in the V2 and V3 regions of HIV-1 gp120 as correlates of infection risk in the RV144 vaccine efficacy trial. PLoS One 8:e75665. http://dx.doi.org/10 .1371/journal.pone.0075665.

30. Zolla-Pazner S, DeCamp AC, Gilbert PB, Williams C, Yates NL, Williams WT, Howington R, Fong Y, Morris DE, Soderberg KA, Irene C, Reichman C, Pinter A, Parks Robert J, Pitisuttithum P, Kaewkungwal J, Rerks-Ngarm S, Nitayaphan S, Andrews C, O'Connell RJ, Kim JH, Michael NL, Montefiori D, Liao H-X, Haynes BF, Tomaras G. 2014. Vaccine-induced IgG antibodies to V1V2 regions of multiple HIV-1 subtypes correlate with decreased risk of HIV-1 infection. PLoS One 9:e87572. http://dx.doi.org/10.1371/journal.pone.0087572.

31. Yates NL, Liao HX, Fong Y, deCamp A, Vandergrift NA, Williams WT, Alam SM, Ferrari G, Yang ZY, Seaton KE, Berman PW, Alpert MD, Evans DT, O'Connell RJ, Francis D, Sinangil F, Lee C, Nitayaphan S, Rerks-Ngarm S, Kaewkungwal J, Pitisuttithum P, Tartaglia J, Pinter A, Zolla-Pazner S, Gilbert PB, Nabel GJ, Michael NL, Kim JH, Montefiori 
DC, Haynes BF, Tomaras GD. 2014. Vaccine-induced Env V1-V2 IgG3 correlates with lower HIV-1 infection risk and declines soon after vaccination. Sci Transl Med 6:228ra39. http://dx.doi.org/10.1126/scitranslmed .3007730.

32. Pegu P, Vaccari M, Gordon S, Keele BF, Doster M, Guan Y, Ferrari G, Pal R, Ferrari MG, Whitney S, Hudacik L, Billings E, Rao M, Montefiori D, Tomaras G, Alam SM, Fenizia C, Lifson JD, Stablein D, Tartaglia J, Michael N, Kim J, Venzon D, Franchini G. 2013. Antibodies with high avidity to the gp120 envelope protein in protection from simian immunodeficiency virus $\mathrm{SIV}_{\text {mac251 }}$ acquisition in an immunization regimen that mimics the RV-144 Thai trial. J Virol 87:1708-1719. http://dx.doi.org/10 $.1128 /$ JVI.02544-12.

33. Vaccari M, Gordon SN, Fourati S, Schifanella L, Liyanage NP, Cameron M, Keele BF, Shen X, Tomaras GD, Billings E, Rao M, Chung AW, Dowell KG, Bailey-Kellogg C, Brown EP, Ackerman ME, VargasInchaustegui DA, Whitney S, Doster MN, Binello N, Pegu P, Montefiori DC, Foulds K, Quinn DS, Donaldson M, Liang F, Lore K, Roederer M, Koup RA, McDermott A, Ma ZM, Miller CJ, Phan TB, Forthal DN, Blackburn M, Caccuri F, Bissa M, Ferrari G, Kalyanaraman V, Ferrari MG, Thompson D, Robert-Guroff M, Ratto-Kim S, Kim JH, Michael NL, Phogat S, Barnett SW, Tartaglia J, Venzon D, Stablein DM, Alter G, Sekaly RP, Franchini G. 2016. Adjuvant-dependent innate and adaptive immune signatures of risk of SIV acquisition. Nat Med 22:762-770. http://dx.doi.org/10.1038/nm.4105.

34. Barouch DH, Liu J, Li H, Maxfield LF, Abbink P, Lynch DM, Iampietro MJ, SanMiguel A, Seaman MS, Ferrari G, Forthal DN, Ourmanov I, Hirsch VM, Carville A, Mansfield KG, Stablein D, Pau MG, Schuitemaker H, Sadoff JC, Billings EM, Rao M, Robb ML, Kim JH, Marovich MA, Goudsmit J, Michael NL. 2012. Vaccine protection against acquisition of neutralization-resistant SIV challenges in rhesus monkeys. Nature 482:89-93. http://dx.doi.org/10.1038/nature10766.

35. Totrov M, Jiang X, Kong XP, Cohen S, Krachmarov C, Salomon A, Williams C, Seaman MS, Cardozo T, Gorny MK, Wang S, Lu S, Pinter A, Zolla-Pazner S. 2010. Structure-guided design and immunological characterization of immunogens presenting the HIV-1 gp120 V3 loop on a CTB scaffold. Virology 405:513-523. http://dx.doi.org/10.1016/j.virol 2010.06.027.

36. Zolla-Pazner S, Kong X, Jiang X, Cardozo T, Nadas A, Cohen S, Totrov M, Seaman MS, Wang S, Lu S. 2011. Cross-clade HIV-1 neutralizing antibodies induced with V3-scaffold protein immunogens following priming with gp120 DNA. J Virol 85:9887-9898. http://dx.doi.org/10 $.1128 /$ JVI.05086-11.

37. Pan R, Gorny MK, Zolla-Pazner S, Kong XP. 2015. The V1V2 region of HIV-1 gp120 forms a five-stranded beta barrel. J Virol 89:8003-8010. http://dx.doi.org/10.1128/JVI.00754-15.

38. Barouch DH, Alter G, Broge T, Linde C, Ackerman ME, Brown EP, Borducchi EN, Smith KM, Nkolola JP, Liu J, Shields J, Parenteau L, Whitney JB, Abbink P, Ng'ang'a DM, Seaman MS, Lavine CL, Perry JR, Li W, Colantonio AD, Lewis MG, Chen B, Wenschuh H, Reimer U, Piatak M, Lifson JD, Handley SA, Virgin HW, Koutsoukos M, Lorin C, Voss G, Weijtens M, Pau MG, Schuitemaker H. 2015. Protective efficacy of adenovirus/protein vaccines against SIV challenges in rhesus monkeys. Science 349:320-324. http://dx.doi.org/10.1126/science.aab3886.

39. Li M, Salazar-Gonzalez JF, Derdeyn CA, Morris L, Williamson C, Robinson JE, Decker JM, Li Y, Salazar MG, Polonis VR, Mlisana K, Karim SA, Hong K, Greene KM, Bilska M, Zhou J, Allen S, Chomba E, Mulenga J, Vwalika C, Gao F, Zhang M, Korber BT, Hunter E, Hahn BH, Montefiori DC. 2006. Genetic and neutralization properties of subtype $\mathrm{C}$ human immunodeficiency virus type 1 molecular env clones from acute and early heterosexually acquired infections in Southern Africa. J Virol 80:11776-11790. http://dx.doi.org/10.1128/JVI.01730-06.

40. Wang S, Farfan-Arribas DJ, Shen S, Chou TH, Hirsch A, He F, Lu S. 2006. Relative contributions of codon usage, promoter efficiency and leader sequence to the antigen expression and immunogenicity of HIV-1 Env DNA vaccine. Vaccine 24:4531-4540. http://dx.doi.org/10.1016/j .vaccine.2005.08.023.

41. Zolla-Pazner S, Cohen SS, Krachmarov C, Wang S, Pinter A, Lu S. 2008. Focusing the immune response on the V3 loop, a neutralizing epitope of the HIV-1 gp120 envelope. Virology 372:233-246. http://dx.doi.org/10 .1016/j.virol.2007.09.024.

42. Ross SA, Sarisky CA, Su A, Mayo SL. 2001. Designed protein G core variants fold to native-like structures: sequence selection by ORBIT toler- ates variation in backbone specification. Protein Sci 10:450 - 454. http://dx .doi.org/10.1110/ps.32501.

43. Song J, Gao X, Galan JE. 2013. Structure and function of the Salmonella Typhi chimaeric $A_{2} B_{5}$ typhoid toxin. Nature 499:350-354. http://dx.doi .org/10.1038/nature12377.

44. Yildiz O, Kalthoff C, Raunser S, Kuhlbrandt W. 2007. Structure of GlnK1 with bound effectors indicates regulatory mechanism for ammonia uptake. EMBO J 26:589-599. http://dx.doi.org/10.1038/sj.emboj.7601492.

45. Zhang P, Du J, Sun B, Dong X, Xu G, Zhou J, Huang Q, Liu Q, Hao Q, Ding J. 2006. Structure of human MRG15 chromo domain and its binding to Lys36-methylated histone H3. Nucleic Acids Res 34:66216628. http://dx.doi.org/10.1093/nar/gkl989.

46. Reeves PJ, Callewaert N, Contreras R, Khorana HG. 2002. Structure and function in rhodopsin: high-level expression of rhodopsin with restricted and homogeneous $\mathrm{N}$-glycosylation by a tetracycline-inducible $\mathrm{N}$ acetylglucosaminyltransferase I-negative HEK293S stable mammalian cell line. Proc Natl Acad Sci U S A 99:13419-13424. http://dx.doi.org/10.1073 /pnas.212519299.

47. Jiang X, Totrov M, Li W, Sampson JM, Williams C, Lu H, Wu X, Lu S, Wang S, Zolla-Pazner S, Kong X-P. 2016. Rationally designed immunogens targeting HIV-1 gp120 V1V2 induce distinct conformation-specific antibody responses in rabbits. J Virol 90:11007-11019. http://dx.doi.org /10.1128/JVI.01409-16.

48. Ackerman ME, Moldt B, Wyatt RT, Dugast AS, McAndrew E, Tsoukas S, Jost S, Berger CT, Sciaranghella G, Liu Q, Irvine DJ, Burton DR, Alter G. 2011. A robust, high-throughput assay to determine the phagocytic activity of clinical antibody samples. J Immunol Methods 366:8-19. http://dx.doi.org/10.1016/j.jim.2010.12.016.

49. McLellan JS, Pancera M, Carrico C, Gorman J, Julien JP, Khayat R, Louder R, Pejchal R, Sastry M, Dai K, O’Dell S, Patel N, Shahzad-ul Hussan S, Yang Y, Zhang B, Zhou T, Zhu J, Boyington JC, Chuang GY, Diwanji D, Georgiev I, Kwon YD, Lee D, Louder MK, Moquin S, Schmidt SD, Yang ZY, Bonsignori M, Crump JA, Kapiga SH, Sam NE, Haynes BF, Burton DR, Koff WC, Walker LM, Phogat S, Wyatt R, Orwenyo J, Wang LX, Arthos J, Bewley CA, Mascola JR, Nabel GJ, Schief WR, Ward AB, Wilson IA, Kwong PD. 2011. Structure of HIV-1 gp120 V1/V2 domain with broadly neutralizing antibody PG9. Nature 480:336-343. http://dx.doi.org/10.1038/nature10696.

50. Kayman SC, Wu Z, Revesz K, Chen H, Kopelman R, Pinter A. 1994 Presentation of native epitopes in the V1/V2 and V3 regions of human immunodeficiency virus type 1 gp120 by fusion glycoproteins containing isolated gp120 domains. J Virol 68:400-410.

51. Li J, Valentin A, Kulkarni V, Rosati M, Beach RK, Alicea C, Hannaman D, Reed SG, Felber BK, Pavlakis GN. 2013. HIV/SIV DNA vaccine combined with protein in a co-immunization protocol elicits highest humoral responses to envelope in mice and macaques. Vaccine 31:37473755. http://dx.doi.org/10.1016/j.vaccine.2013.04.037.

52. Rusert P, Krarup A, Magnus C, Brandenberg OF, Weber J, Ehlert AK, Regoes RR, Gunthard HF, Trkola A. 2011. Interaction of the gp120 V1V2 loop with a neighboring gp120 unit shields the HIV envelope trimer against cross-neutralizing antibodies. J Exp Med 208:1419-1433. http: //dx.doi.org/10.1084/jem.20110196.

53. Julien J-P, Cupo A, Sok D, Stanfield RL, Lyumkis D, Deller MC, Klasse P-J, Burton DR, Sanders RW, Moore JP, Ward AB, Wilson IA. 2013. Crystal structure of a soluble cleaved HIV-1 envelope trimer. Science 342: 1477-1483. http://dx.doi.org/10.1126/science.1245625.

54. Kwon YD, Pancera M, Acharya P, Georgiev IS, Crooks ET, Gorman J, Joyce MG, Guttman M, Ma X, Narpala S, Soto C, Terry DS, Yang Y, Zhou T, Ahlsen G, Bailer RT, Chambers M, Chuang GY, Doria-Rose NA, Druz A, Hallen MA, Harned A, Kirys T, Louder MK, O'Dell S, Ofek G, Osawa K, Prabhakaran M, Sastry M, Stewart-Jones GB, Stuckey J, Thomas PV, Tittley T, Williams C, Zhang B, Zhao H, Zhou Z, Donald BR, Lee LK, Zolla-Pazner S, Baxa U, Schon A, Freire E, Shapiro L, Lee KK, Arthos J, Munro JB, Blanchard SC, Mothes W, Binley JM, McDermott AB, Mascola JR, Kwong PD. 2015. Crystal structure, conformational fixation and entry-related interactions of mature ligand-free HIV-1 Env. Nat Struct Mol Biol 22:522-531. http://dx.doi.org/10.1038/nsmb .3051 .

55. Mayr LM, Cohen S, Spurrier B, Kong X-P, Zolla-Pazner S. 2013. Epitope mapping of conformational V2-specific anti-HIV human monoclonal antibodies reveals an immunodominant site in V2. PLoS One 8:e70859. http://dx.doi.org/10.1371/journal.pone.0070859.

56. Spurrier B, Sampson J, Gorny MK, Zolla-Pazner S, Kong XP. 2014. 
Functional implications of the binding mode of a human conformationdependent V2 monoclonal antibody against HIV. J Virol 88:4100-4112. http://dx.doi.org/10.1128/JVI.03153-13.

57. Corti D, Langedijk JP, Hinz A, Seaman MS, Vanzetta F, FernandezRodriguez BM, Silacci C, Pinna D, Jarrossay D, Balla-Jhagjhoorsingh S, Willems B, Zekveld MJ, Dreja H, O'Sullivan E, Pade C, Orkin C, Jeffs SA, Montefiori DC, Davis D, Weissenhorn W, McKnight A, Heeney JL, Sallusto F, Sattentau QJ, Weiss RA, Lanzavecchia A. 2010. Analysis of memory B cell responses and isolation of novel monoclonal antibodies with neutralizing breadth from HIV-1-infected individuals. PLoS One 5:e8805. http://dx.doi.org/10.1371/journal.pone.0008805.

58. Gorny MK, Moore JP, Conley AJ, Karwowska S, Sodroski J, Williams C, Burda S, Boots LJ, Zolla-Pazner S. 1994. Human anti-V2 monoclonal antibody that neutralizes primary but not laboratory isolates of HIV-1. J Virol 68:8312-8320.

59. Gorny MK, Pan R, Williams C, Wang XH, Volsky B, O’Neal T, Spurrier B, Sampson JM, Li L, Seaman MS, Kong XP, Zolla-Pazner S. 2012. Functional and immunochemical cross-reactivity of V2-specific monoclonal antibodies from human immunodeficiency virus type 1-infected individuals. Virology 427:198-207. http://dx.doi.org/10.1016/j.virol.2012 .02 .003 .

60. Klein F, Nogueira L, Nishimura Y, Phad G, West AP, Jr, HalperStromberg A, Horwitz JA, Gazumyan A, Liu C, Eisenreich TR, Lehmann C, Fatkenheuer G, Williams C, Shingai M, Martin MA, Bjorkman PJ, Seaman MS, Zolla-Pazner S, Karlsson Hedestam GB, Nussenzweig MC. 2014. Enhanced HIV-1 immunotherapy by naturally arising antibodies targeting resistant variants. J Exp Med 211:2361-2372. http://dx .doi.org/10.1084/jem.20141050.

61. Israel ZR, Gorny MK, Palmer C, McKeating JA, Zolla-Pazner S. 1997. Prevalence of a V2 epitope in clade B primary isolates and its recognition by sera from HIV-1 infected individuals. AIDS 11:128-130.

62. Walker LM, Phogat SK, Chan-Hui PY, Wagner D, Phung P, Goss JL, Wrin T, Simek MD, Fling S, Mitcham JL, Lehrman JK, Priddy FH, Olsen OA, Frey SM, Hammond PW, Miiro G, Serwanga J, Pozniak A, McPhee D, Manigart O, Mwananyanda L, Karita E, Inwoley A, Jaoko W, Dehovitz J, Bekker LG, Pitisuttithum P, Paris R, Allen S, Kaminsky S, Zamb T, Moyle M, Koff WC, Poignard P, Burton DR. 2009. Broad and potent neutralizing antibodies from an African donor Reveal a new HIV-1 vaccine target. Science 326:285-289. http://dx.doi .org/10.1126/science.1178746.

63. Bonsignori M, Hwang K-K, Chen X, Tsao C-Y, Morris L, Gray E, Marshall DJ, Crump JA, Kapiga SH, Sam NE, Sinangil F, Pancera M, Yongping Y, Zhang B, Zhu J, Kwong PD, O'Dell S, Mascola JR, Wu L, Nabel GJ, Phogat S, Seaman MS, Whitesides JF, Moody MA, Kelsoe G, Yang X, Sodroski J, Shaw GM, Montefiori DC, Kepler TB, Tomaras GD, Alam SM, Liao H-X, Haynes BF. 2011. Analysis of a clonal lineage of HIV-1 envelope V2/V3 conformational epitope-specific broadly neutralizing antibodies and their inferred unmutated common ancestors. J Virol 85:9998-10009. http://dx.doi.org/10.1128/JVI.05045-11.

64. Wu X, Changela A, O'Dell S, Schmidt SD, Pancera M, Yang Y, Zhang B, Phogat S, Gorny MK, Robinson JE, Stamatatos L, Zolla-Pazner S, Kwong PD, Mascola JR. 2011. Immunotypes of a quaternary structure of the HIV-1 envelope affect viral vulnerability to neutralizing antibodies. J Virol 85:4578-4585. http://dx.doi.org/10.1128/JVI.02585-10.

65. Palker TJ, Matthews TJ, Clark ME, Cianciolo GJ, Randall RR, Langlois AJ, White GC, Safai B, Snyderman R, Bolognesi DP, Haynes BF. 1987. A conserved region at the $\mathrm{COOH}$ terminus of human immunodeficiency virus gp120 envelope protein contains an immunodominant epitope. Proc Natl Acad Sci U S A 84:2479-2483. http://dx.doi.org/10.1073/pnas 84.8.2479.

66. LaRosa GJ, Davide JP, Weinhold K, Waterbury JA, Profy AT, Lewis JA, Langlois AJ, Dreesman GR, Boswell RN, Shadduck P, Holley LH, Karplus M, Bolognesi DP, Matthews TJ, Emini EA, Putney SD. 1990. Conserved sequence and structural elements in HIV-1 principal neutralizing determinant. Science 249:932-935. http://dx.doi.org/10.1126 /science.2392685

67. Upadhyay C, Mayr LM, Zhang J, Kumar R, Gorny MK, Nadas A, Zolla-Pazner S, Hioe CE. 2014. Distinct mechanisms regulate exposure of neutralizing epitopes in the V2 and V3 loops of HIV-1 envelope. J Virol 88:12853-12865. http://dx.doi.org/10.1128/JVI.02125-14.
68. Pegu A, Yang Z-y, Boyington JC, Wu L, Ko S-Y, Schmidt SD, McKee K, Kong W-P, Shi W, Chen X, Todd J-P, Letvin NL, Huang J, Nason MC, Hoxie JA, Kwong PD, Connors M, Rao SS, Mascola JR, Nabel GJ. 2014. Neutralizing antibodies to HIV-1 envelope protect more effectively in vivo than those to the CD4 receptor. Sci Transl Med 6:243ra88. http://dx.doi .org/10.1126/scitranslmed.3008992.

69. Rappuoli R. 2000. Reverse vaccinology. Curr Opin Microbiol 3:445-450. http://dx.doi.org/10.1016/S1369-5274(00)00119-3.

70. Delany I, Rappuoli R, Seib KL. 2013. Vaccines, reverse vaccinology, and bacterial pathogenesis. Cold Spring Harb Perspect Med 3:a012476. http: //dx.doi.org/10.1101/cshperspect.a012476.

71. McLellan JS, Chen M, Joyce MG, Sastry M, Stewart-Jones GBE, Yang Y, Zhang B, Chen L, Srivatsan S, Zheng A, Zhou T, Graepel KW, Kumar A, Moin S, Boyington JC, Chuang G-Y, Soto C, Baxa U, Bakker AQ, Spits H, Beaumont T, Zheng Z, Xia N, Ko S-Y, Todd J-P, Rao S, Graham BS, Kwong PD. 2013. Structure-based design of a fusion glycoprotein vaccine for respiratory syncytial virus. Science 342:592-598. http: //dx.doi.org/10.1126/science.1243283.

72. Arnold GF, Velasco PK, Holmes AK, Wrin T, Geisler SC, Phung P, Tian Y, Resnick DA, Ma X, Mariano TM, Petropoulos CJ, Taylor JW, Katinger H, Arnold E. 2009. Broad neutralization of human immunodeficiency virus type 1 (HIV-1) elicited from human rhinoviruses that display the HIV-1 gp41 ELDKWA epitope. J Virol 83:5087-5100. http://dx .doi.org/10.1128/JVI.00184-09.

73. Liang X, Munshi S, Shendure J, Mark G 3rd, Davies ME, Freed DC, Montefiori DC, Shiver JW. 1999. Epitope insertion into variable loops of HIV-1 gp120 as a potential means to improve immunogenicity of viral envelope protein. Vaccine 17:2862-2872. http://dx.doi.org/10 .1016/S0264-410X(99)00125-5.

74. Zhang H, Huang Y, Fayad R, Spear GT, Qiao L. 2004. Induction of mucosal and systemic neutralizing antibodies against human immunodeficiency virus type 1 (HIV-1) by oral immunization with bovine papillomavirus-HIV-1 gp41 chimeric virus-like particles. J Virol 78:8342-8348. http://dx.doi.org/10.1128/JVI.78.15.8342-8348.2004.

75. Ofek G, Guenaga FJ, Schief WR, Skinner J, Baker D, Wyatt R, Kwong PD. 2010. Elicitation of structure-specific antibodies by epitope scaffolds. Proc Natl Acad Sci U S A 107:17880-17887. http://dx.doi.org/10.1073 /pnas.1004728107.

76. Zhou T, Zhu J, Yang Y, Gorman J, Ofek G, Srivatsan S, Druz A, Lees CR, Lu G, Soto C, Stuckey J, Burton DR, Koff WC, Connors M, Kwong PD. 2014. Transplanting supersites of HIV-1 vulnerability. PLoS One 9:e99881. http://dx.doi.org/10.1371/journal.pone.0099881.

77. Sips M, Krykbaeva M, Diefenbach TJ, Ghebremichael M, Bowman BA, Dugast AS, Boesch AW, Streeck H, Kwon DS, Ackerman ME, Suscovich TJ, Brouckaert P, Schacker TW, Alter G. 17 February 2016. Fc receptormediated phagocytosis in tissues as a potent mechanism for preventive and therapeutic HIV vaccine strategies. Mucosal Immunol http://dx.doi .org/10.1038/mi.2016.12.

78. Robinson HL. 2013. Non-neutralizing antibodies in prevention of HIV infection. Expert Opin Biol Ther 13:197-207. http://dx.doi.org/10.1517 /14712598.2012.743527.

79. Hessell AJ, Hangartner L, Hunter M, Havenith CE, Beurskens FJ, Bakker JM, Lanigan CM, Landucci G, Forthal DN, Parren PW, Marx PA, Burton DR. 2007. Fc receptor but not complement binding is important in antibody protection against HIV. Nature 449:101-104. http://dx .doi.org/10.1038/nature06106.

80. Chung AW, Crispin M, Pritchard L, Robinson H, Gorny MK, Yu X, Bailey-Kellogg C, Ackerman ME, Scanlan C, Zolla-Pazner S, Alter G. 2014. Identification of antibody glycosylation structures that predict monoclonal antibody Fc-effector function. AIDS 28:2523-2530. http://dx .doi.org/10.1097/QAD.0000000000000444.

81. Bournazos S, Klein F, Pietzsch J, Seaman MS, Nussenzweig MC, Ravetch JV. 2014. Broadly neutralizing anti-HIV-1 antibodies require Fc effector functions for in vivo activity. Cell 158:1243-1253. http://dx.doi .org/10.1016/j.cell.2014.08.023.

82. Huber M, Trkola A. 2007. Humoral immunity to HIV-1: neutralization and beyond. J Intern Med 262:5-25. http://dx.doi.org/10.1111/j $.1365-2796.2007 .01819 . x$. 